\title{
Materials in harnessing solar power
}

\author{
MARKA SANDEEP KUMAR ${ }^{1}$, NAGAVOLU CHARANADHAR ${ }^{1}$, VADALI V S S SRIKANTH ${ }^{1, *}$ VD, $^{\text {, }}$ \\ KOTA BHANU SANKARA RAO ${ }^{2}$ and BALDEV RAJ ${ }^{3, \dagger}$ \\ ${ }^{1}$ School of Engineering Sciences and Technology, University of Hyderabad, Hyderabad 500046, India \\ ${ }^{2}$ Mahatma Gandhi Institute of Technology, Hyderabad 500075, India \\ ${ }^{3}$ National Institute of Advanced Studies, Indian Institute of Science Campus, Bengaluru 560012, India \\ *Author for correspondence (vvsssse@uohyd.ernet.in)
}

MS received 15 July 2017; accepted 10 November 2017; published online 6 April 2018

\begin{abstract}
Harnessing renewable solar energy through different technologies is greatly dependent on the advancement of solar grade materials' science and engineering. In this article, the prominent solar energy technologies, namely solar photovoltaic and concentrated solar power and other relevant technologies, and aspects related to various solar grade materials, influence of nanomaterials on enhancement of solar energy harvest, technology-market relations, development of hybrid systems etc., are discussed. The inspiration to write this article is not only to review the existing technologies to harvest solar energy but also to highlight the pertinent and possible solutions thereof, especially from materials perspective.
\end{abstract}

Keywords. Renewable solar energy; solar PV technology; concentrated solar power; materials; thin films; nanomaterials.

\section{Introduction}

At present, harnessing 'renewable energy' is one of the most sought-after objectives in the world. Ever increasing worldwide energy demand for terrestrial applications is going deplete the conventional energy resources $[1,2]$ in a very short time. In order to challenge and meet the growing demandparticularly in some of the emerging and developing countries where per capita energy availability is less than needed for quality life-scientists, engineers and technologists have been developing economically viable and sustainable energy solutions, which offer clean, continuous and reliable energy on a large-scale [3]. In this context, recently, a wide-ranging plan named 'Wind, Water and Solar (WWS)' power has been outlined [4]. WWS power plan does not involve the use of any non-renewable energy resources. Owing to the exponential increase in technology, it is anticipated that by 2030, WWS power would satisfy all the energy demands in the world and by 2050, all contemporary energy resources could be appropriately transformed to WWS power. However, it was discerned that the only constraints for the proper implementation of WWS power plan would be of only social and political nature. It was also discerned that the energy costs in the WWS powered world would be similar to that of the present day's energy costs.

Energy Information Administration (EIA), U.S. Department of Energy and International Energy Outlook, has projected that by 2030, the entire world requires a total usable power of $\sim 17$ TW. However, such a requirement cannot be

\footnotetext{
${ }^{\dagger}$ Baldev Raj: Deceased.
}

met with the depleting fossil fuels and hence it was recognized that the WWS power systems are the only means to supply sustainable energy. Amongst all the identified WWS technologies such as wind, wave, geothermal, hydroelectric, tidal, concentrated solar power (CSP) and solar photovoltaic (PV) technologies, solar PV technology was found to be the dominant one owing to obvious advantages it brings-in. The primary advantage is in the incidence of solar radiation equivalent to $\sim 6500 \mathrm{TW}$ on the land and ocean surfaces together [5]. Practically, a total terrestrial solar power of $\sim 340 \mathrm{TW}$ (which is $\sim 20$ times greater than the required end-use power) is deliverable using solar PV technology alone [5]. Furthermore, other WWS technologies can be set-up at places where wind, wave and hydrothermal sources are abundant as compared to the solar radiation to supplement solar PV energy supply. It is worth mentioning that as solar PV technology advances, the energy costs decrease, which is another pertinent advantage.

Like many countries, solar energy is underutilized by India too. India receives solar radiation of $\sim 200 \mathrm{MW} \mathrm{km}^{-2} \mathrm{~h}^{-1}$ [6]. In India, solar radiation incidence is 4 to $7 \mathrm{kWh} \mathrm{m}^{-2}$ per day whilst the sunshine's time is in the range 2300-3200 h per year [7]. In January 2010, Ministry of New and Renewable Energy (MNRE), Government of India, started Jawaharlal Nehru National Solar Mission (JNNSM) [8] to boost India's solar energy harnessing capability. The mission document of JNNSM states that India aims to harness grid-connected solar power (extracted from solar PV and CSP technologies together) of at least $20 \mathrm{GW}$ by the year 2022, with other short-term goals in three phases [9]. In line with the aim, as of 29 May 2015, India's total grid-connected solar energy 
commissioned capacity was $\sim 3883.5$ MW [10], with major contribution from solar PV power plants. To further enhance India's energy harnessing capacity, certain key problems have to be carefully solved. The problems are as follows: (a) solar PV technology is still not independent of climatic conditions and therefore it is considered as an intermittent energy provider, which requires additional energy storage systems to complement the losses in tapping energy due to changes in climatic conditions, (b) solar grade materials which are used to fabricate solar cells are still very costly and/or unavailable in India; therefore, solar PV technology's output is not yet costeffective, (c) large areas required to install grid-connected solar plants are not easily available owing to social and political constraints and inadequate government policies in this respect and (d) poor research and development (R\&D) pertaining to off-grid hybrid power systems based on power generated through solar PV technology. There are also problems associated with energy storage systems. For example, if a typical battery is considered for storing energy, charging it using the power generated by solar PV technology is difficult because the energy output from solar PV system is continuously varying due to continuous variations in the climatic conditions. In other words, it is not possible to have an optimal charge-discharge cycle for the battery, therefore high state of charge (SOC) is not possible, which in turn shortens the battery's life owing to sulphation and stratification. To overcome the above-mentioned problem, hybrid energy storage system, for example, a system constituted by valve-regulated lead acid (VRLA) battery and supercapacitor has been developed [11]. Through the hybrid energy storage system, the peak power for the end-use is supplied by the supercapacitor, while the lower continuous power for the end-use is supplied by VRLA. Further improvement can be achieved by incorporating fuel cell in the hybrid system along with the battery and supercapacitor. The fuel cell supplies steady state to average end-use demand and helps in overcoming the deficiencies created by the fluctuating output of solar PV power. The battery acts in such a way that the peaking duration is covered by the maximum allowed charge fluctuation, while the supercapacitor can be suitably rated to sufficiently cover the transients between the maximum and minimum voltage fluctuations. The inclusion of the fuel cell in the fabrication of hybrid energy storage system was effective in greatly enhancing the power availability and reducing the usage of battery [12]. Further, a suitable battery such as Li ion battery can be used as a power backup. As per the present-day energy storage device technology, the battery design should be in such a way that it can provide a balance among specific energy and power, and life, obtaining optimum values of which is difficult. Therefore, it has been suggested that the energy-storage system should be a hybrid of the energy - the power source [13]. Based on this concept, solar cells and fuel cells (as specific energy sources), and supercapacitors (as high-specific power sources) are hybridized to form a stabilized power source. This concept was demonstrated by using hydrogen fuel cell system (Ballard Nexa Fuel Cell System (1.2 kW, 46 A)) in parallel with Si PV (Ekarat
Solar Company (800 W, 31 A)) and supercapacitor module (BCAP1200, Maxwell Technologies, 100 F, 32 V). The solar $\mathrm{PV}$ array was configured by connecting four panels (each with a capacity of $200 \mathrm{~W}, 7.78 \mathrm{~A}$ ) in series. The supercapacitor had 12 cells connected in series to achieve a capacitance of $1200 \mathrm{~F}$ and a maximum voltage of $2.7 \mathrm{~V}$. The above demonstration proved that it is possible to produce grid-connected hybrid sustainable power systems. Currently, such a technology is only at a demonstration stage, i.e., such systems deliver enduse power only on a small scale. Scaling-up requires further developments in technologies related to individual components. Nonetheless, it is very clear that harvesting intermittent solar energy, its storage and its uninterrupted supply are possible. In particular, as supercapacitor technology progresses, it may even be possible to exclude battery from the hybrid systems; this needs development of unique electrode materials. On the other hand, it should be recognized that many of dayto-day requirements, such as household lighting or charging personal electronic appliances, do not require large amounts of power. For these purposes, smaller, off-grid hybrid systems with less energy output are sufficient and if these systems are considered on a large scale, say through government policies in countries such as India or by means of adopting remote villages by non-profitable and non-government organizations, a paradigm shift in domestication of solar energy will definitely take place.

With the advent of nano-science and technology, it is postulated that nanomaterials can revolutionize solar PV technology. In other words, cost-effective solar PV technology with high solar energy conversion efficiencies is possible with nanomaterials. It has been observed that nanomaterials exhibit enhanced photon absorption and photo-carrier collection efficiencies [14] and the enhanced solar PV output is based on novel PV mechanisms [15] because nanomaterials' characteristics like quantum confinement, bandgap, work function, etc. are intrinsic in nature and can be controlled to deliver enhanced solar energy conversion efficiencies by easy synthesis/processing procedures.

All emerging solar energy harvesting technologies are greatly dependent on the availability of natural solar grade materials, as shown in figure 1 [16] and/or on the advancement of materials engineering and understanding of science at small length scales (i.e., phenomena associated with solar grade nanomaterials). Si is the most abundant element [16], therefore Si-based solar PV technology is now operational. The highest conversion efficiency for Si-based solar cells reported until date is $25.6 \%$ [17]. Solar PV cells are typically made from polycrystalline Si or poly-Si wafers. Poly-Si wafers (which are either mono-crystalline or polycrystalline) are made from metallurgical grade Si. Nearly $90 \%$ of solar PV technology is based on Poly-Si, while silver is used for electrical front contact grids.

In this review, the prominent solar energy technologies namely solar PV and CSP and other relevant technologies, and aspects related to various solar grade materials, influence of nanomaterials, technology-market relations, development of 


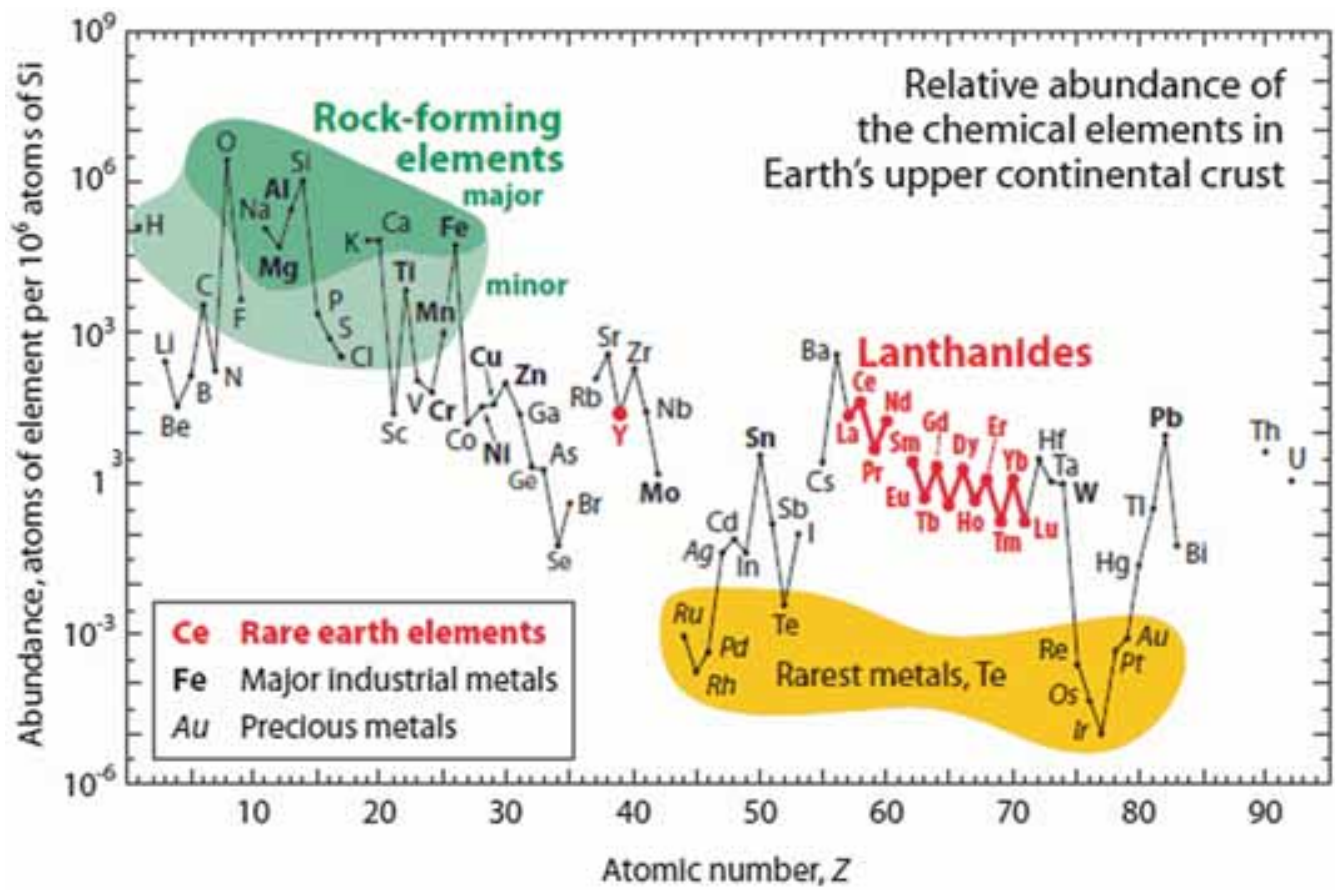

Figure 1. Abundance of various elements in Earth's upper continental crust. Si is one among the most abundant elements [16].

hybrid systems etc. are discussed. This article aims to review the existing technologies for harvesting solar energy and also to highlight the pertinent challenges in different technologies and possible solutions thereof, especially from materials perspective.

\section{Solar PV technology}

\subsection{Current status}

At the end of the year 2015, the total grid-connected cumulative solar energy commissioned capacities in China, Germany, Japan, USA, Italy, UK, France, Spain, Australia and India are $43.5,39.7,34.4,25.6,18.9,8.8,6.6,5.4,5.1$ and $5 \mathrm{GW}$, respectively [18]. India plans to scale-up certified technologies (mainly those based on thin film solar cells) with grid parity by the year 2017 and increase the harnessing capacities to 20, 100 and $200 \mathrm{GW}$ by the years 2022, 2030 and 2050, respectively. Through 'The Solar Mission 2020', Government of India has projected various goals and time-lines to achieve the same [19]. Here it is important to note that in the years 2014 and 2015 India could commission grid-connected cumulative solar energy capacity of $2 \mathrm{GW}$, which is a commendable achievement. Owing to the realization of urgent need to harvest solar energy and its positive implications, the Government of India has initiated the concept of 'special economic zones' through which land, water, electricity and other financial incentives are provided to the developers. This initiative allows the companies from all over the world to establish their plants and technologies by the year 2022 as per JNNSM. In this context, one of the major plans that were announced was by Titan Energy (Indian maker) and Enfinity to install 1 GW capacity solar PV systems in erstwhile Andhra Pradesh, India. PLG Power Renewable Limited (Indian maker) has planned to set-up $450 \mathrm{MW}$ power plants [20]. On the other hand, Tata BP Solar and Calyon Bank are jointly planning to raise huge investments for developmental work. Tata BP Solar has 84 and 124 MW capacities of solar cells and modules manufacturing capabilities and has plans to enhance the capacities.

In India, manufacturing of solar PV modules has been on swift rise but primarily it is highly dependent on the imported $\mathrm{Si}$ wafers. Therefore, the need to promote Si production and related technologies has been recognized. In this context, it is worth mentioning that, in its $\mathrm{XI}^{\text {th }}$ plan Government of India has proposed to allocate 1.2 billion (from the National Energy Fund) to encourage making of polycrystalline $\mathrm{Si}$ in India. It is also noteworthy to mention that MNRE and Ministry of Power [21] propose to make it compulsory for those who want to develop solar PV in India to obtain Si-based modules only from domestic makers. At the same time, MNRE would still allow the import of solar cells. Manufacturing of thin-film modules (even though these are less efficient at present), which are less expensive than crystalline Si-based modules, are also being encouraged in India. For example, Signet Solar, a U.S. company and TF Solar Power, an Indian company have been planning to produce thin-film modules in a big way. Poseidon Solar, an Indian Si recycling company is now capable of recycling solar PV modules based on Cd-Te 
thin-films, thereby rendering significant cost reduction. Research has shown that multi-junction solar cells can offer promising results; R\&D of these cells is being pursued in India. In the recent past, even though the number of solar PV cells' and modules' manufactures and suppliers has increased, the number might not be good enough to meet the goals with respect to the solar energy harvesting capacity in the specified time.

\subsection{Materials for solar PV technology}

2.2a General background: In solar PV technology, solar radiation is directly converted into electrical energy by a solar cell, which is typically made of a solar grade semiconducting material (like $\mathrm{Si}, \mathrm{GaAs}, \mathrm{CdTe}, \mathrm{Cu}(\mathrm{In}, \mathrm{Ga}, \mathrm{S}) \mathrm{Se}_{2}$ (CIGS) and/or other suitable semiconductors), which gets exposed to sunlight to generate electric power, the amount of which depends typically on solar radiation's intensity, solar cell's active surface area, the type of solar grade material with which the solar cell is fabricated, and the ambient temperature. Solar PV cells are typically $\mathrm{p}-\mathrm{n}$ junction-based devices, which are constituted by materials in the form of thick (few hundreds of microns) or thin films (few microns) in single as well as multi-layered configurations such that they absorb solar radiation. The principle of solar PV technology is as follows: the semiconducting material with which the solar cell is fabricated absorbs solar radiation (i.e., photons) and generates electron-hole pairs, which dissociate through the $\mathrm{p}-\mathrm{n}$ junction or equivalent interfaces in the solar cell, and finally the charge carriers are collected at the conducting contacts of the cell.

However, there are limitations with respect to the conversion efficiencies of $\mathrm{p}-\mathrm{n}$ junction based PV solar cells. For example, for a PV solar cell based on a $\mathrm{p}-\mathrm{n}$ junction made of a single solar grade semiconducting material, the conversion efficiency is dependent on the bandgap of the semiconductor. The conversion efficiency of only $\sim 30 \%$ can be achieved using materials with their bandgaps in the range $1.2-1.5 \mathrm{eV}$. In this case, the maximum photo-voltage $\left(V_{\max }\right)$ is given by $V_{\max }=\left(E_{\mathrm{g}} / \mathrm{e}\right)$, where $E_{\mathrm{g}}$ is the bandgap of the solar grade material and $\mathrm{e}$ is the charge on the electron. Therefore, the conversion efficiency is limited for a particular bandgap because the photons of energy less than the bandgap energy are not absorbed and do not contribute to the conversion efficiency. However, with time the solar PV technology has improved from high cost and high efficiency $1^{\text {st }}$ generation $(1 \mathrm{G})$ thick crystalline $\mathrm{Si} / \mathrm{GaAs}$ wafer-based solar cells to low-cost and low-efficiency $2^{\text {nd }}$ generation $(2 \mathrm{G})$ amorphous or polycrystalline $\mathrm{Si}, \mathrm{CdTe}$ and CIGS thin filmbased solar cells. Further improvement in the understanding of materials science and development of novel materials' processing techniques has resulted in inexpensive and highly efficient $3^{\text {rd }}$ generation $(3 \mathrm{G})$ solar cells, which are based on nanocrystalline thin films, quantum dots and tandem or stacked multilayers of inorganic materials based on III-V compounds. 3G solar cells' family also consists of organic (or polymer) solar cells and dye-sensitized solar cell (DSSC) or semiconductor-sensitized solar cells, which work on hotcarriers concept. At present, low-cost and high-efficient $4^{\text {th }}$ generation (4G) solar PV technology, which is based on flexible polymer thin films, is still under research and development stage [22]. The timeline of $1 \mathrm{G}-4 \mathrm{G}$ solar cells is shown in figure 2 .

\section{2b Materials in conventional Si-based solar cells}

The conventional Si-based $\mathrm{p}-\mathrm{n}$ junction solar cell configuration is shown in figure 3a. The p-region is B-doped Si wafer, while n-region is P-doped Si. The front electrical contacts as shown in figure $3 \mathrm{a}$ are typically made of $\mathrm{Ag}$ and are used to collect the photoelectrons. The back electrical contact is typically made of $\mathrm{Al}$, which is screen printed on the entire B-doped Si wafer's back surface. The back contact is used to collect the holes. Light absorption losses due to reflection at the front surface are minimized (in other words, light absorption by the solar cell is enhanced) by chemically texturing the front surface of P-doped Si and applying a suitable antireflection coating. The conventional amorphous $\mathrm{Si}(\mathrm{a}-\mathrm{Si})$ thin film solar cell configuration is shown in figure $3 \mathrm{~b}$. In this cell, $\mathrm{p}-\mathrm{n}$ junction is formed by sandwiching thick intrinsic a-Si layer between thin $\mathrm{p}$ - and n-type a-Si regions. The front and back contacts are typically transparent conductive $\mathrm{SnO}_{2}$ and Ag layers, respectively. Enhancing light trapping, which is discussed in the following paragraphs, is an important aspect in these cells.

The highest conversion efficiency for Si-based solar cells reported till date is $25.6 \%$, which is for a heterojunction (with-intrinsic-layer interdigitated back contact) solar cell [17]. The high efficiency of this cell is a result of excellent surface passivation, indicated by high open-circuit voltage $\left(V_{\mathrm{oc}}\right)$ of $740 \mathrm{mV}$ in combination with excellent light trapping indicated by high short-circuit current density $\left(J_{\mathrm{sc}}\right)$ of $42.7 \mathrm{~mA} \mathrm{~cm}^{-2}$ and that too on a cell of thickness less than $100 \mu \mathrm{m}$. Conventionally, light trapping is made effective (i.e., to achieve high $J_{\text {sc }}$ on un-metallized front surfaces) in commercial cells by chemically texturing (with a feature size in the range $3-10 \mu \mathrm{m}$ ) the front surface and applying a suitable anti-reflection coating of thickness less than $100 \mathrm{~nm}$ [23]. However, this concept is not suitable for thinner cells owing to the large feature size on the textured front surface and moreover chemical texturing and applying anti-reflection coating do not render a cost-effective solar cell. In this context, it was found out that nano-structuring (light management through design) could be used to enhance light trapping and improving the conversion efficiency of the solar cells. It is known that small metallic and dielectric particles can strongly scatter light owing to their optical resonances [24], namely surface plasmon and Mie resonances, respectively; this aspect was utilized not only to couple but also to efficiently trap light at the front surface of Si-based solar cells [25]. Moreover, the resonant small metallic and dielectric particles exhibit 


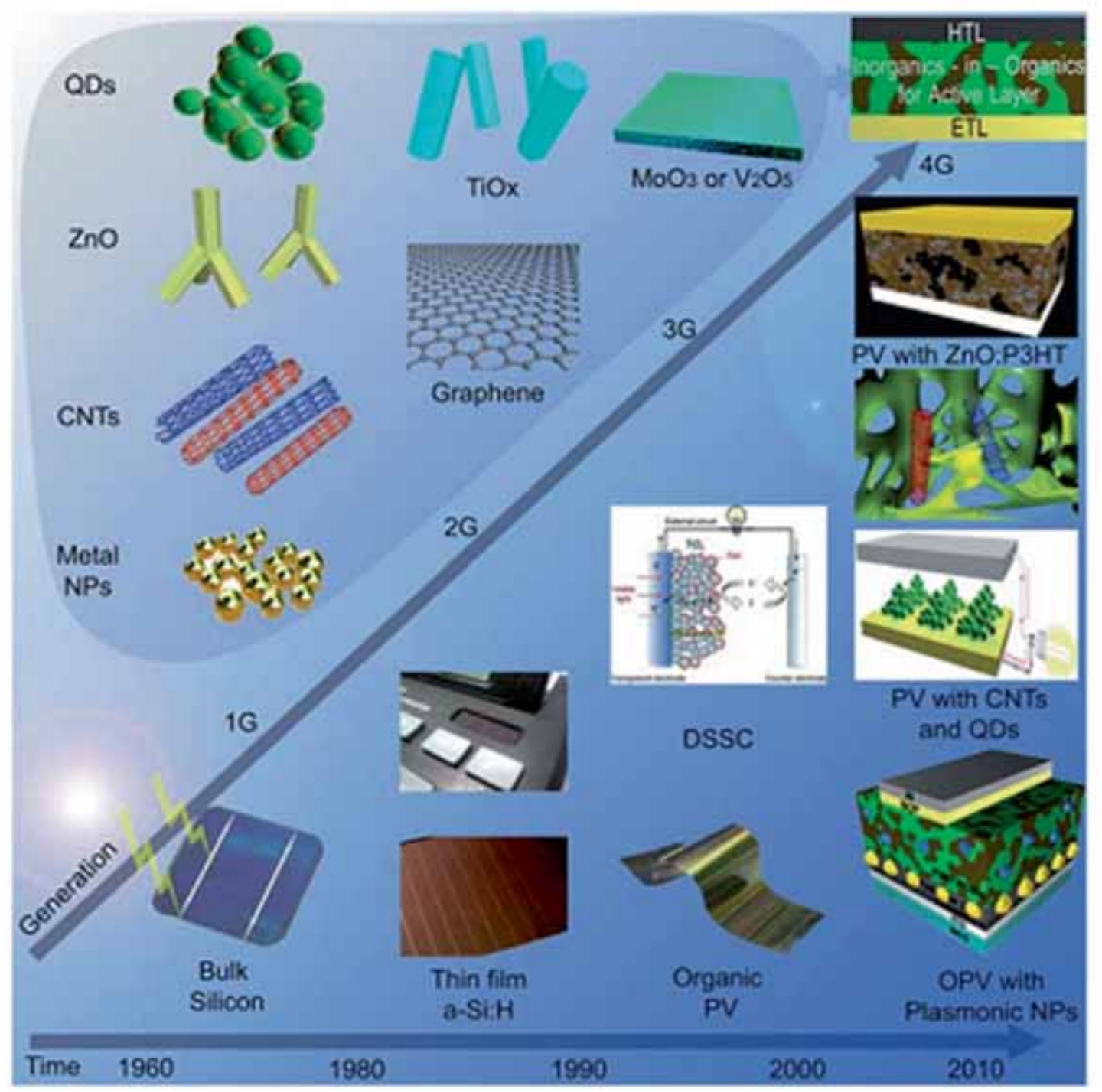

Figure 2. Timeline of different generations of solar cells [22].

light scattering cross-sections that are much larger than the geometrical areas of the scattering particles themselves; this aspect permits enhanced interaction of the small particles with the incident light even when these cover less than $30 \%$ of the front surface area [26]. Further, the scattered light by the resonant particles prefers to travel towards nearby materials with high density of optical states, i.e., materials with high refractive index [27]; this aspect helped to augment the light absorption in solar cells fabricated using materials with high refractive index. The strong light scattering allowed enhancement of light absorption by the solar cell and thereby the enhancement in number of photoelectrons per unit area (i.e., $J_{\mathrm{sc}}$ ). Smoother the front-end surface (anti-reflection coating), lesser is the surface recombination of charge carriers and thereby enhancement in $V_{\text {oc }}$; this is what exactly happens when nanostructuring/nanopatterning is used [28]. Additionally, metal particles can also be inter-connected and used as an electrode in the solar cell. It has been shown that transparent Ag nanowire networks [29] can be formed as a conductive electrode, which can replace $\mathrm{SnO}_{2}$ (shown in figure 3b) or in general transparent conductive oxides used as front contacts. This approach renders photocurrent extraction more effective, decreases the series resistance, and thereby enhances the fillfactor of the solar cell. In the case of small dielectric particles, at resonance, the light is confined in well-defined geometrical modes (Mie resonances) inside the resonant particles [24], which are used to couple the strongly scattered light (due to Mie resonance) preferentially into the high refractive index possessing crystalline $\mathrm{Si}$. It is important to also make a note that the small metallic and dielectric particles can be used on 
(a)

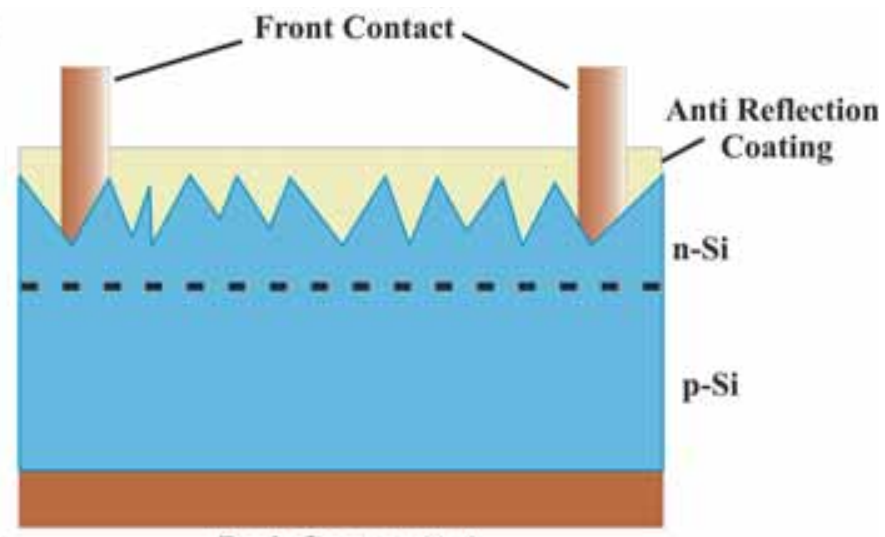

Back Contact (Ag)

(b)

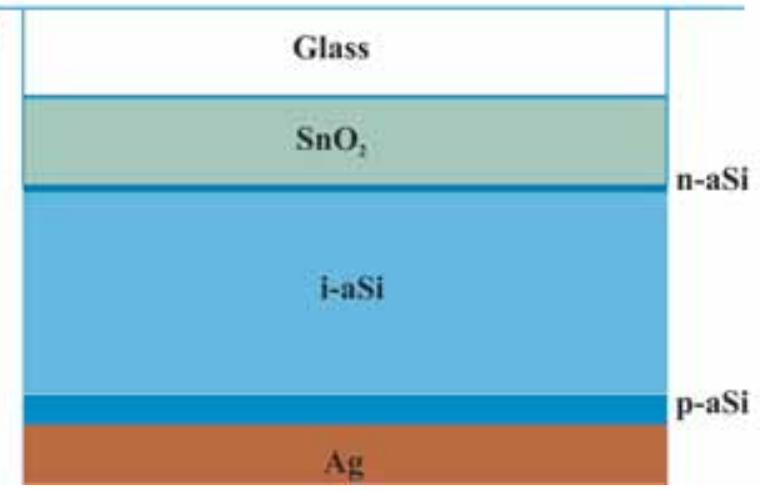

Figure 3. Schematics of typical (a) p-n junction Si and (b) a-Si solar cell configurations.

(a)

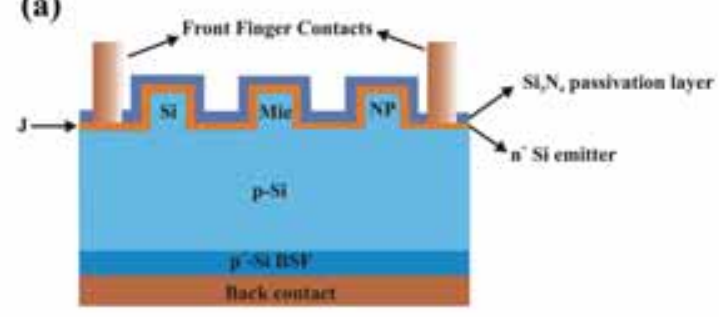

(c)

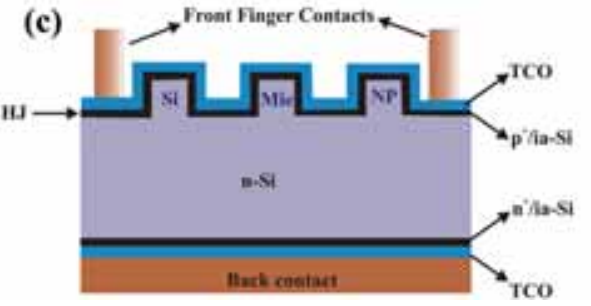

(b)

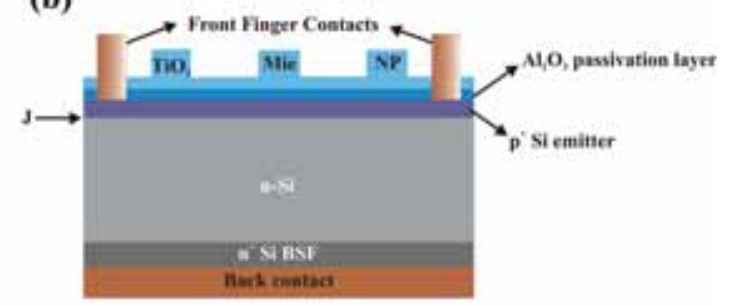

(d)

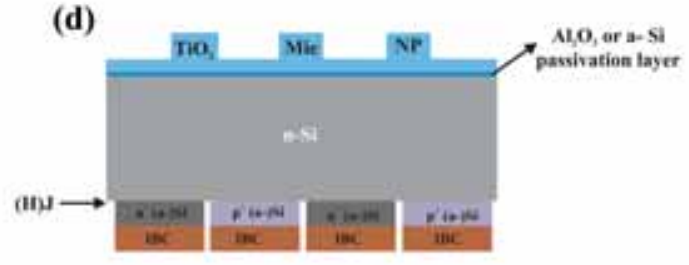

Figure 4. Schematic of interdigitated back contact (IBC) homo- (or hetero-) junction solar cell with a TiO $\mathrm{Mie}$ coating.

not only the front [30] and backsides [31] of the cell but also inside [32] the active material of the solar cell.

As mentioned before, the crystalline Si-based solar cell with the highest efficiency ever is a heterojunction-interdigitated back contact (IBC)-back-junction (figure 4), which implies that the junction and the conductive contacts are at the backside of the cell, which has interdigitated finger configuration constituted by alternating highly p-doped $\mathrm{Si}$ regions forming the junction with highly n-doped regions forming back surface fields to repel minority charge carriers. 
The front side of the cell can either be textured or flat, the later reduces the surface recombination of charges. In a flat front side configuration, a thin $\mathrm{Al}_{2} \mathrm{O}_{3}$ /intrinsic a-Si: $\mathrm{H}$ passivation layer is used (when n-type $\mathrm{Si}$ is the active material) to create an inversion near the front surface where holes become majority charge carriers [33]. On the passivation layer, $\mathrm{TiO}_{2} \mathrm{Mie}$ resonant layer is applied for anti-reflection and light trapping purposes.

Owing to the above-described design, shadowing/ recombination is nullified at the front side of the cell while light absorption is enhanced due to the mediation of Mie coating, which is now overlapped with the active layer and decoupled from the highly doped emitter region, which is at the backside in the present configuration. Materials, namely $\mathrm{Ag}$ (surface plasmonic type) [34] and $\mathrm{Si}$ and $\mathrm{TiO}_{2}$ (Mie type) [35], have been considered as resonant particles for anti-reflection, light trapping and surface passivation purposes and to minimize parasitic losses. $\mathrm{TiO}_{2}$ has rendered excellent results in terms of enhancing the conversion efficiency of the solar cell in comparison to $\mathrm{Si}$ and $\mathrm{Ag}$ used for the same purposes. Ethyl vinyl acetate which is a typical material used as an encapsulation on the solar cell's front side against weathering has also enhanced the anti-reflection effect in the Si-based solar cells integrated with Mie resonant coatings than with surface plasmon resonant particles [36].

\section{2c Thin film materials}

Due to the decreasing availability of crystalline $\mathrm{Si}$ and back contact materials such as Ag, and brittleness of Si, thin filmbased solar PV technologies were developed as alternatives to Si-based technologies. Thin film-based solar cells are fabricated by depositing thin films of solar grade materials (mainly CdTe, CIGS, GaAs and amorphous $\mathrm{Si}$ ) on low-cost and easily available substrates such as glass, stainless steel, plastic and so on. Thin film solar cells work on the same principle to that of $\mathrm{p}-\mathrm{n}$ junction Si-based solar cells except that the cells are much thinner, the active $\mathrm{p}$ - and n-type materials are different and the front and back contacts are different. CdS is the most common n-type material used to form $\mathrm{p}-\mathrm{n}$ junction with the other p-type active materials mentioned above. Multiple junction solar cells can also be fabricated with the same set of materials. At present, the record conversion efficiency is greater than $46 \%$ for the multi-junction solar cell based on GaAs, and it is between 22.1 and $25.6 \%$ for single junction cells ( $\mathrm{Si}$, CIGS, CdTe), while it is between 13 and $21 \%$ for recently developed solar cells [17] such as DSSC, organic solar cell and quantum dots solar cell. Of late, hybrid organic-inorganic solar cells based on perovskite materials have exhibited record efficiencies (as high as 22\%). Organic-inorganic halide perovskite materials have also gained importance owing to their high power conversion efficiency (PCE) values and their costeffectiveness compared to conventional Si solar cells. These materials are typically represented by the chemical formula
$\mathrm{AMX}_{3}$ ( $\mathrm{A}$ and $\mathrm{M}$ being cations while $\mathrm{X}$ being anion; Aorganic, M-divalent metal ions, X-halide). Structurally, A and $\mathrm{M}$ cations are at the eight corners and body centre position, respectively, of the cubic unit cell, while $\mathrm{M}$ is bonded by six $\mathrm{X}$ anions situated at the face centre position. Usually $\mathrm{CH}_{3} \mathrm{NH}_{3}^{+}, \mathrm{C}_{2} \mathrm{H}_{5} \mathrm{NH}_{3}^{+}, \mathrm{HC}\left(\mathrm{NH}_{2}\right)^{2+}$ etc. are used as A cations, while $\mathrm{Pb}^{2+}, \mathrm{Sn}^{2+}, \mathrm{Eu}^{2+}, \mathrm{Cu}^{2+}$ etc. are used as $\mathrm{M}$ cations and $\mathrm{Cl}^{-}, \mathrm{Br}^{-}$and $\mathrm{I}^{-}$are used as $\mathrm{X}$ anions. In this context, $\mathrm{CH}_{3} \mathrm{NH}_{3} \mathrm{PbI}_{3}$ is an excellent example of organic-inorganic halide perovskite (figure 5) [37].

In 2009, perovskite-sensitized solar cell $\left(\mathrm{CH}_{3} \mathrm{NH}_{3} \mathrm{PbI}_{3}\right.$ is the light absorber coated on $\mathrm{TiO}_{2}$ mesoporous layers and electrolytes are halides) with a significant PCE of $3.81 \%$ was fabricated [38]. Moreover, the cell exhibited an excellent photo-voltage of $0.96 \mathrm{~V}$ when $\mathrm{CH}_{3} \mathrm{NH}_{3} \mathrm{PbBr}_{3}$ was used as the light absorber. However, instability of the liquid electrolyte and dissolution of the perovskites in the liquid electrolyte were the drawbacks. Later, PCE and stability of the cell was improved by using spiro-OMeTAD as a solid-state hole transporter and $\mathrm{CH}_{3} \mathrm{NH}_{3} \mathrm{PbI}_{3}$ and $\mathrm{CH}_{3} \mathrm{NH}_{3} \mathrm{PbI}_{3-x} \mathrm{Cl}_{x}$ as light absorbers. It should be noted that the fabrication of organicinorganic perovskite solar cells is easy and cost-effective compared to the conventional Si-based solar cells. The fabrication involves firstly the deposition of $\mathrm{a} \mathrm{TiO}_{2}$ hole-blocking layer on a typical FTO substrate. Then, a layer of n-type $\mathrm{TiO}_{2}$ (which is mesoporous in nature) is either screen-printed or spin-coated using a paste of $\mathrm{TiO}_{2}$ nanoparticles/polymer binder. As a next step, annealing is done to remove the binder. On top of the mesoporous $\mathrm{TiO}_{2}$ layer, perovskite film is deposited from solvents such as $\gamma$-butyrolactone or $N, N$ dimethylformamide by spin-coating. To further improve the conductivity, a hole transporter layer such as spiro-OMeTAD is applied on the perovskite. Finally, a transparent metal electrode is deposited as the top most layer to enable most of the incoming solar radiation to reach the active material and thereby resulting in the generation of charge carriers. Moreover, the coloured perovskite- and dye-sensitized solar cells with transparent electrodes enhance the aesthetic value of the buildings, in which these solar cells are integrated into the architectural glass. Based on this basic multi-layered configuration, different experiments were conducted by manipulating the materials' characteristics in each layer to improve the conversion efficiencies with better $V_{\text {oc }}$ values. Out of all the manipulations, the thickness of mesoporous $\mathrm{TiO}_{2}$ was found to greatly affect the PCE values of the cell [39-41]. On the other hand, similar configuration without the hole transporter showed a conversion efficiency of 5.5\% [42,43]. The conversion efficiency was enhanced to $8 \%$ by varying the perovskite layer thickness. Later, meso-superstructured solar cell configuration (in which an $\mathrm{Al}_{2} \mathrm{O}_{3}$ layer (which is both mesoporous and insulating in nature)) is deposited on the top of the $\mathrm{TiO}_{2}$ [44-47]. $\mathrm{Al}_{2} \mathrm{O}_{3}$ layer acted as a scaffold that aided loading of the active perovskite material (mostly $\mathrm{CH}_{3} \mathrm{NH}_{3} \mathrm{PbI}_{3-x} \mathrm{Cl}_{x}$ ) in it [44-47]. It was observed that the electron transport occurs within the perovskite unlike in the case of mesoporous $\mathrm{TiO}_{2}$ perovskite configuration and this leads to increase in 
(a)
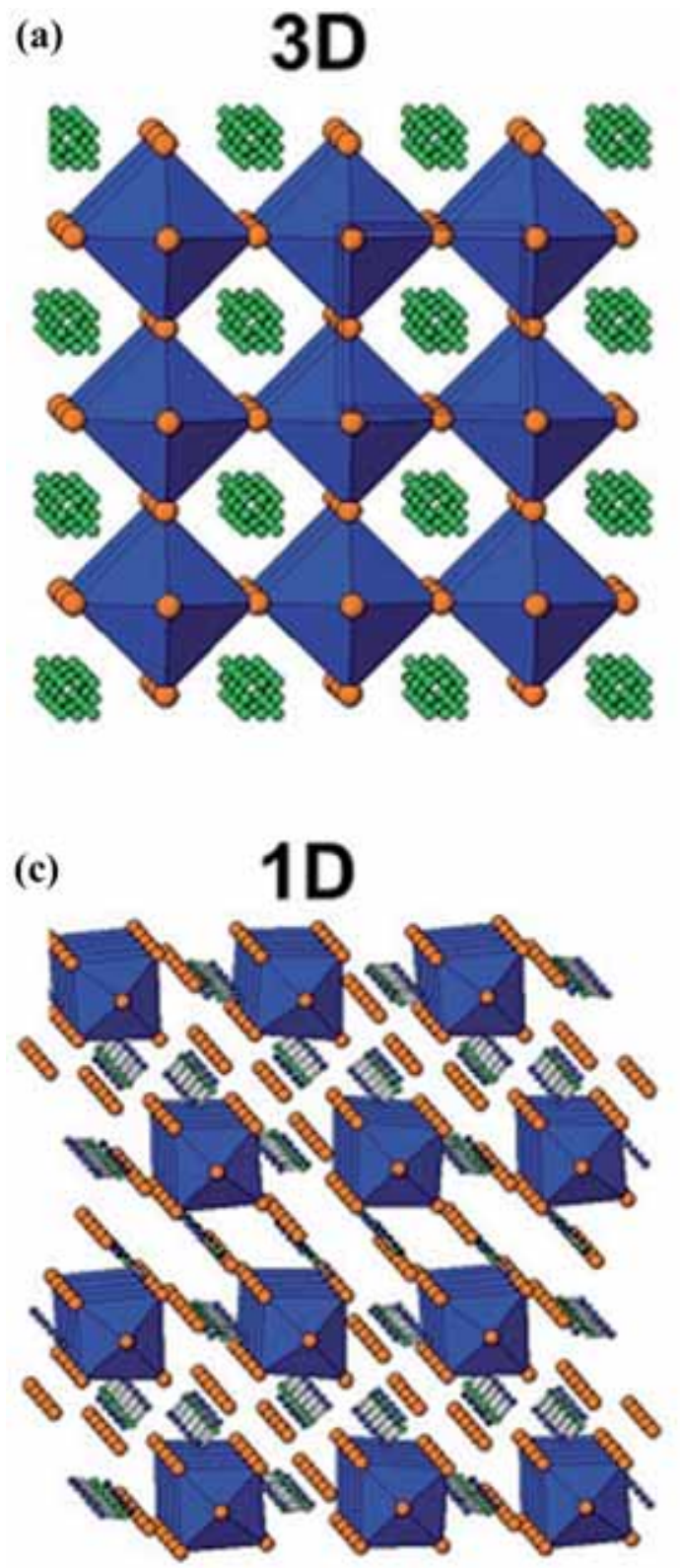

(b)

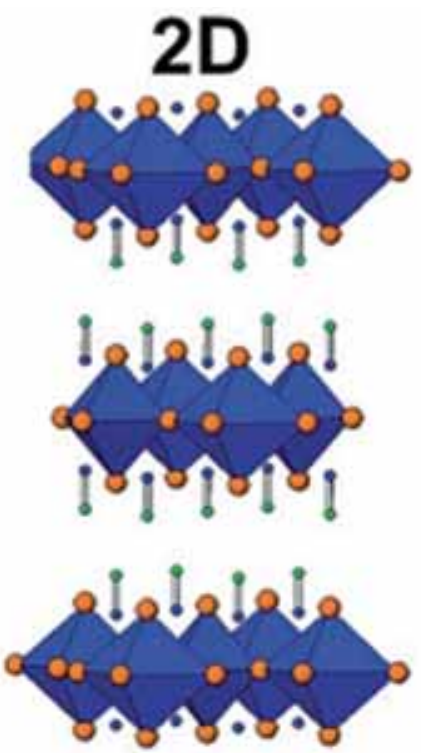

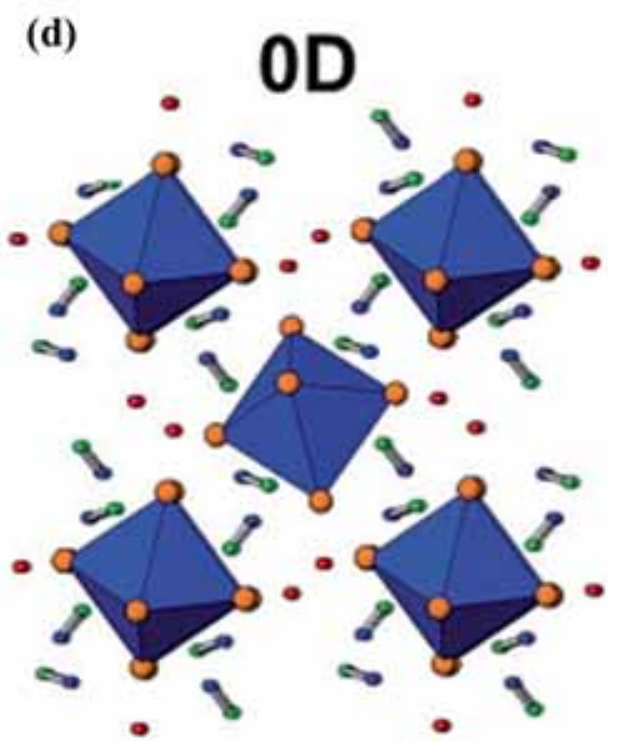

Figure 5. Crystal structures of (a) $\mathrm{CH}_{3} \mathrm{NH}_{3} \mathrm{PbI}_{3}$, (b) $\left(\mathrm{CH}_{3} \mathrm{NH}_{3}\right)_{2} \mathrm{PbI}_{4}$, (c) $\left(\mathrm{C}_{10} \mathrm{H}_{21} \mathrm{NH}_{3}\right)_{2} \mathrm{PbI}_{4}$ and (d) $\left(\mathrm{CH}_{3} \mathrm{NH}_{3}\right)_{4} \mathrm{PbI}_{6} \cdot 2 \mathrm{H}_{2} \mathrm{O}$, corresponding to $3 \mathrm{D}, 2 \mathrm{D}, 1 \mathrm{D}$ and $0 \mathrm{D}$ networks. The blue polyhedral represents the $\mathrm{MX}_{6}(\mathrm{M}=\mathrm{Pb}, \mathrm{Sn}$ and $\mathrm{Cu} ; \mathrm{X}=\mathrm{I}$ and $\mathrm{Br})$ octahedral with the halogens represented by orange spheresthe building blocks of these compounds. The blue, green and red spheres are the $\mathrm{N}, \mathrm{C}$ and $\mathrm{O}$, respectively ( $\mathrm{H}$ atoms are removed for clarity). The ID network extends into the plane of the page [37].

$V_{\mathrm{oc}}$ values of the cell due to accumulation of charge in the perovskite. Recently, phase stable $\mathrm{CsPbI}_{3}$ perovskite-based solar cell with conversion efficiency of $10.77 \%$ and $V_{\text {oc }}$ of $1.23 \mathrm{~V}$ (equivalent to e.m.f. of a battery) has been fabricated [48]. In another study, mesoscopic $\mathrm{CH}_{3} \mathrm{NH}_{3} \mathrm{PbI}_{3} / \mathrm{TiO}_{2}$ heterojunction with a double layer of $\mathrm{TiO}_{2}$ and $\mathrm{ZrO}_{2}$ as scaffold and carbon as back contact was shown to deliver a power conversion efficiency (PCE) of $12.8 \%$ and exhibit long-term stability [49]. Further uniform crystal growth of perovskite material was obtained using a two-step process, in which, first $\mathrm{PbI}_{2}$ was spin coated from dimethylformamide onto the mesoporous $\mathrm{TiO}_{2}$ film and then exposed to $\mathrm{CH}_{3} \mathrm{NH}_{3} \mathrm{I}$ in isopropanol to form the final perovskite pigment that penetrated the mesoporous $\mathrm{TiO}_{2}$. This configuration increased the PCE to $15 \%$ with an excellent reproducibility [50]. Recently, PCE of $17.01 \%$ was achieved by spin coating $\mathrm{CH}_{3} \mathrm{NH}_{3} \mathrm{PbI}_{3}$ cuboids [51]. Recently, Prof Grazel's research team has achieved a record PCE of $21.1 \%$ with Ce containing first triple cation 
perovskite mixture. These films are more heat stable and less affected by experimental environment, and a PCE of $18 \%$ was also observed ever after $250 \mathrm{~h}$ exposure to operational conditions [52]. Apart from the above presented advantages, stability and toxicity are major challenges for commercializing perovskite solar cells. To overcome the toxicity issue, lead-free perovskite solar cells with Sn replacement were proposed. These cells exhibited conversion efficiencies of $\sim 6 \%$ $[53,54]$.

CdTe cells made by First Solar Inc., Arizona, USA, and CdSe cells made by Bloo Solar Inc., California, USA, have unique layered structures. These cells have shown good results. CIGS cells are relatively new amongst the thin filmbased metal-semiconductor solar cells. CIGS cells not only exhibit higher conversion efficiencies but are also less costly. Unfortunately, CIGS cells are very sensitive to moisture. This drawback has hindered their full commercialization. The commercialized CIGS cells exhibit efficiency of $\sim 15 \%$, whilst the developmental CIGS cells exhibit efficiency up to $\sim 20 \%$. In India, for example, ARCI (an autonomous DST Research Centre), Hyderabad, is developing the large area CIGS thin film-based solar cells. An interesting aspect of solar cells with CIGS technology is that the optical bandgap can be graded by varying the dopant (III A group elements like Ga (from 1.0 to $1.7 \mathrm{eV}$ ) or $\mathrm{Al}$ (from 1.0 to $2.7 \mathrm{eV}$ )). They can also be fabricated by wet chemical root. For better junction, Aldoped $\mathrm{ZnO}$ as an electron donor layer for CIASe active layer with $\mathrm{Al}$ contacts showed a good external quantum efficiency of around 35\% [55]. Parallel to the development of metal and semiconductor-based thin-film solar cells, organic thin-film solar cells are also being developed. These solar cells are fabricated by dissolving organic semiconductors in solvents or inks, which are either printed or coated onto plastic substrates in a continuous roll-to-roll process. In this context, knifeover-edge, slotdie and gravure coating methods are wellpracticed [56,57], as they give an idea about ink parameters in correlation to the interaction between the ink and the surface that is to be coated, which is very important for manufacturing high volume solar modules in quick time. The use of nanomaterials in these cells has been observed to trap enhanced energy [58]. Commercial triple junction thin-film solar cells made by Emcore Photovoltaics and Spectrolab exhibited efficiency of $\sim 38 \%$. At the same time, there is still a great scope for all the advancements that are at present limited to laboratories. Another interesting set of modules are the flexible thin-film modules with plastic front sheets, which are mostly the transparent monolayer fluoropolymer films such as ETFE or its derivatives. Rowland Technologies Inc., Wallingford, made front sheet named Rowlar (using Arkema's Kynar PVDF), which shows light transmission greater than $93 \%$ and haze less than $9 \%$. However, India is lagging behind in research and development related to organic thin-film-based solar cells. As discussed in the previous section, preferential light scattering by resonant particles can also be used to enhance light trapping and coupling into GaAs, CdTe or CIGS thin-film-based solar cells. For enhanced light trapping, surface plasmon resonant particles can be embedded in low refractive index materials such as perovskites and organic materials used in thin film solar cells [32].

Recently, DSSCs have attracted a great attention because these are expected to challenge Si-based solar cells and compete for a significant market share in next-generation solar cells. This is owing to their good performance even under diffuse light, lower production costs, innate solution processability, which allows easy fabrication of large area cells, and excellent unit price per performance metric, which allows these to gain grid parity. DSSC typically consists of a photo-anode, an electrolyte with redox species (such as iodide/tri-iodide $\left(\mathrm{I}^{-} / \mathrm{I}_{3}^{-}\right)$in an organic solvent), and a counter electrode (CE). The anode consists of a transparent conducting oxide (TCO)-coated glass substrate with a layer of mesoporous network of wide bandgap metal oxide semiconductor, such as $\mathrm{TiO}_{2}$, which is sensitized with a suitable dye. The redox couple in the electrolyte works as a mediator that transfers electrons from the cathode to the oxidized dye molecules. $\mathrm{I}^{-}$ions reduce the sensitizer and oxidize to $\mathrm{I}_{3}^{-}$ions, while the monovalent $\mathrm{I}^{-}$ions are recovered at the cathode. Commonly, Pt-coated TCO-coated glass substrate is used as the CE because of platinum's high catalytic activity and resistance to corrosion due to the electrolyte. However, due to platinum's high cost and low corrosion resistance to the iodide-based electrolytes, scientists have investigated both alternative CEs and other redox couple electrolytes other than iodide/tri-iodide $\left(\mathrm{I}^{-} / \mathrm{I}_{3}^{-}\right)$. These alternative electrolytes, such as anion-doped PEDOT, have assisted in producing stable solid-state DSSCs. Instead of Pt, a number of carbon-based materials including graphene-related materials have been tested as alternative CE materials, which exhibited excellent conductivity and high electro-catalytic activity. Even though the efficiencies of DSSCs with graphene-related materials (graphene obtained through electrophoretic deposition and graphene with incorporation of $\mathrm{SiO}_{2}$ nanoparticles) as CE materials are high (5.69 and 4.04\%), the fabrication of devices involve complex process steps and therefore require optimization of a number of process parameters. In another important work, the efficiency of DSSC with photothermal reduced graphene oxide (P-rGO) as CE was 7.62\%, the method used for fabricating the final $\mathrm{CE}$ may not be suitable for realizing large area CEs. In the case of graphene-based composites as CE materials in DSSCs, it is difficult to understand and control the electrochemical activity at the electrode/electrolyte interface. However, graphene ink spray coated on FTO substrates was recently used as a $\mathrm{CE}$ in fabricating large-area DSSC modules via the spray coating technique. Here, the electrochemical activity at the electrode/electrolyte interface could be easily explained. Additionally, using a CE composed of graphene nanoplatelets (GNP), in the structure FTO/Au/GNP, produced a DSSC with a record efficiency of over $14 \%$, outperforming a similar FTO/Pt CE DSSC. In both cases, the electrolyte was cobalt(III/II) tris $(1,10$ phenanthroline) complex $\left(\left[\mathrm{Co}(\mathrm{phen})^{3+/ 2+}\right]\right)$ transition metal 
redox couple system with $\mathrm{TiO}_{2}$ electrodes co-photosensitized with a strongly anchored alkoxysilyl-dye, namely ADEKA-1 and a carboxy-organic dye, namely LEG4. In a recent work [59], an easy fabrication process of robust DSSCs with graphene oxide and solar reduced graphene oxide as $\mathrm{CE}$ materials and nanocrystalline $\mathrm{TiO}_{2}$ photo-anode was demonstrated. The novel points of this work are as follows: (i) integrating an excellent photo-anode into DSSC, (ii) easy and renewable method of preparing $\mathrm{CE}$ materials without any metallic layer or in composite form, (iii) spray coating of $\mathrm{CE}$ materials facilitating the fabrication of large area CEs, (iv) energy conversion efficiency of $\sim 4 \%$ (without using Pt or any CE material in composite form), comparable to the values exhibited by DSSCs with graphene composites and (v) owing to the innate nature of the CE materials used in this work, the electrochemical activity at the electrode/electrolyte interface could be easily explained. This work can lead to all carbon electrode DSSC or similar solar cells with enhanced efficiency. Since similar electrolytes can be used for fabricating supercapacitors, hybridizing DSSC with supercapacitors is possible to obtain self-powered photosupercapacitor devices; but such concepts are still in the research stage [60-62]. In this connection, graphene can be used in different components and also as a substrate and common platform [63].

\section{2d Nanoscience in solar PV}

Even though Schockley-Queisser (SQ) limit was surpassed by multi-junction solar cells, commercialization of these solar cells is yet to be realized. By utilizing the science at small length scales (i.e., using nanomaterials and the related novel physics) too, SQ limit can be surpassed. One of the earliest solar cells which used 'interpenetrated junctions' or 'bulk heterojunctions' are DSSCs, whose mechanism was explained in the previous section. These cells worked on 'geometric confinement effect' at a small length scale, namely the 'nanoscale'. Unlike in the conventional PV solar cell, the incident light absorption volume was made less than the charge carriers' diffusion length. The thickness of the absorbing material was made a few $\mathrm{nm}$ to a few tens of $\mathrm{nm}$. Donor and acceptor nanomaterials (both organic and inorganic nanowires and nanorods) occupied the space between $n$ and $\mathrm{p}$ regions of the solar cell. By geometrically confining the active material domains, effective separation of charge carriers was possible. P3HT and PCBM mixture was the most used organic material in polymer bulk heterojunction solar cells. The highest efficiency using the concept of geometric confinement was $11.7 \%$ [64]. However, transport of charges to the electrodes is poor in these cells. One way to overcome this problem is to have vertical donor material nanowires (with diameter in the order of the exciton diffusion length and length equivalent to the carriers' diffusion length to the electrodes) embedded in an acceptor material matrix in such a way that the nanowires act as percolation paths to the electrodes.
Another way to augment solar cells' conversion efficiency is by using nanostructures (dots, wires, tubes etc.) that exhibit quantum confinement effect, which renders wave-like behaviour to electrons and the carrier transport is strongly confined in a given dimension. The nanostructures are embedded in a material, in which the electron wavefunctions do not overlap. In the case of $\mathrm{Si}, \mathrm{Ge}, \mathrm{PbS}$ etc., the nanostructures are embedded in the matrix of an insulating material such that the transfer of electrons takes places from one nanostructure to the other in the matrix through the tunneling effect owing to the wave nature of the electron. The quantum effect in nanoparticles increases the bandgap of the material, i.e., the bandgap of Si quantum dots can be varied from 1.3 to $3 \mathrm{eV}$ by decreasing their size from 5 to $1.2 \mathrm{~nm}$. Theoretically, it was predicted that for all-Si tandem cell, which utilizes the quantum effects of Si nanostructures there will be an enormous increase in $V_{\mathrm{oc}}$ (owing to larger bandgap in Si nanostructures) and thereby an efficiency solely based on quantum effects can be as high as $29 \%$ [65].

\subsection{Materials constraint for the development of solar PV technology}

If not for the constraint laid by availability of feedstock of materials and materials processing technologies to meet the production rate of solar PV modules, achieving gigawatts (GW) level of power through solar PV in the near future may not be an impossible reality. As mentioned earlier, the fabrication of solar PV modules and integrated systems depends greatly on the availability of common materials (used in fabrication of different segments other than the actual power generating segments of a typical solar PV system), such as Ag, $\mathrm{Cu}$, plastics and polymers, glass materials, steels, construction materials (such as cement and concrete) etc., and also unique materials such as $\mathrm{Si}$, In, Te, Se etc., depending on the type of solar PV being developed. In order to meet the materials demand in fabrication of solar PV systems, there should be an increase in the production of the above-mentioned materials and their availability to meet the huge demand [66]. For example, in the case of CIGS- and CdTe-based solar PV systems, the development is hindered by the limited availability of In and Te. Therefore, there is a need for the development of efficient methods to refine primary ores of In and Te. In the case of Te, its extraction from Mn nodules on the seabed has to be rigorously taken up. At the same time, there is also a need to simultaneously enhance $\mathrm{Zn}$ and $\mathrm{Cu}$ extraction. Improvement in solar PV technology could also be mainly driven by:

(1) Technologies that could use thinner layers than those used today

(2) Recovering and using materials that are lost during layer fabrication and

(3) Finding substitution (for example, indium) for elements such as gallium or aluminium. 


\section{CSP technology}

CSP technology uses concentrated solar radiation to convert solar energy into electricity through thermal route. The possibility of including thermal storage systems in CSP technology makes it advantageous over solar PV technology. The inclusion of thermal storage systems also makes it possible to supply power continuously without impeding the grid's stability. The basic principle of CSP technology is as follows: the incident radiation is collected and concentrated by suitable mirrors to generate heat that in turn heats a suitable heat transfer fluid (HTF), which generates steam or hot gas, which is ultimately used to run a heat engine. In CSP technology, higher is the operating temperature of the heat engine, greater is the efficiency of the whole set-up. However, attaining the optimal efficiency can be hindered by unwanted rise in temperature of the collector. Every solar cell requires a threshold photon energy equivalent (to the bandgap of the solar grade material used to fabricate the cell) for the conversion of photons into electric power. However, there is every possibility (depending on the type of solar cell and the weather conditions under which the system works) that at least $50 \%$ of the incident solar radiation can be converted into heat resulting in undesired rise in temperature, which in turn can result in reduction in cell efficiency and structural damage of the cell. The remedy for this is use of air (or water) stream that continuously takes away the heat and does not allow the rise in temperature [67]. The systems that use this technology are called photovoltaic thermal (PVT) hybrid solar systems. On the other hand, in thermal power plants coal is extensively used to generate electricity and in doing so, environment is polluted. It is beneficial to propose hybrid systems such as combination of CSP, coal and thermal systems, which reduces usage of coal and leads to reduction in pollution. This is useful in many domestic applications such as tap water heating for household necessaries, swimming pool heating etc. In India's context, by the end of the year 2022, JNNSM is aiming to tap substantial amount of power (at least $10 \mathrm{GW}$ ) through grid-connected CSP technology, which is still at R\&D level in India. CERC has already announced feed-in tariff to boost the production of solar collectors in India. In this context, it should also be noted that CSP technology is in use only in few desert regions in the world [68]. North-western region in India has been identified as one of the best places in the world to execute CSP technology. As per a survey by the German Aerospace Centre, nearly 11,000 TWh per year can be generated in India through only CSP technology [68]. This has attracted several companies [69-71] including NTPC [72] to invest and develop CSP technology in India. Government of India through JNNSM has a target of establishing gridconnected CSP in India that can yield 10,000 MW of power by 2022 [73]. It has been recognized that indigenous manufacturing of solar collectors that work at medium and high operating temperatures has to be especially taken up [74]. In addition, the essential components in CSP systems namely concentrating mirrors and receiving tubes can be manufactured in India.
This will not only reduce the cost of CSP technology but can also support any import of CSP technologies and ultimately help in reducing any gap areas related to CSP technology relevant to India.

For CSP technology to succeed in India, importance should be given to indigenously develop HTFs and thermal energy storage systems (TESSs) [75]. The main purpose of HTFs is to transfer heat to and from the storage system. The main characteristics of a good HTF are: low solidification temperature, high evaporation temperature, high thermal stability (even at low pressures), high thermal conductivity, low viscosity, high density and heat capacity, chemical compatibility with other contact materials, low toxicity, environmentally safe, high availability and low cost. Commonly used HTFs are listed in table 1. In parabolic trough CSP technology, temperatures greater than $400^{\circ} \mathrm{C}$ can be achieved. However, at these temperatures, synthetic HTFs (which are otherwise very convenient to use) degrade. With respect to the temperature, molten salts can be used if the temperatures are even greater than $600^{\circ} \mathrm{C}$, but at lower temperatures $\left(\sim 250^{\circ} \mathrm{C}\right)$ which are well below the freezing points of working fluids, they cannot be operated. Therefore, there is an urgent need to develop HTFs that can be operated at temperatures greater than $400^{\circ} \mathrm{C}$ and at the same time they are convenient to use and maintain. On the other hand, TESSs balance the power during the transient periods, supply power to the grid based on the base-load, stabilize the power whenever required and minimize mirrors' defocusing. TESSs in CSP systems are supposed to exhibit high volumetric energy capacity, optimum charging and discharging heat rates, good latent heat storage (at both maximum and minimum temperatures), environmentally benign nature, thermal and chemical stability for all the operational cycles, good compatibility with different surrounding materials, low heat losses and high quality of thermocline after charging.

In the case of CSP plants that operate at low temperatures (i.e., between 170 and $300^{\circ} \mathrm{C}$ ), intermittent energy supply is overcome by using intermediate temperature systems such as power storage systems. The Research Institute for Solar Energy and New Energies (IRESEN) is currently supervising the construction of a 1 MWe CSP plant for power generation (Solar Thermal Electricity), near Benguerir (Morocco), based on linear Fresnel collectors in the solar field and Organic Rankine Cycle (ORC) technology operating on superheated cyclopentane $\left(\mathrm{C}_{4} \mathrm{H}_{10}\right)$ in the power block [77]. The low-cost thermocline system in direct configuration as energy storage management seems to be better than that of two-tank technology for small to medium size ORC solar power plants. The study shows that thermocline system in direct configuration with priority to energy storage strategy dumps off more energy than that of priority to power block strategy. A power plant combined with both strategies is suggested.

In the case of parabolic trough-based CSP systems, the manufacturing cost is the greatest hindrance factor. Ray tracing analysis shows that if the design and functioning of the reflector involves mere bending of flat reflecting sheet, the concentration ratio falls short of engineering applications' 


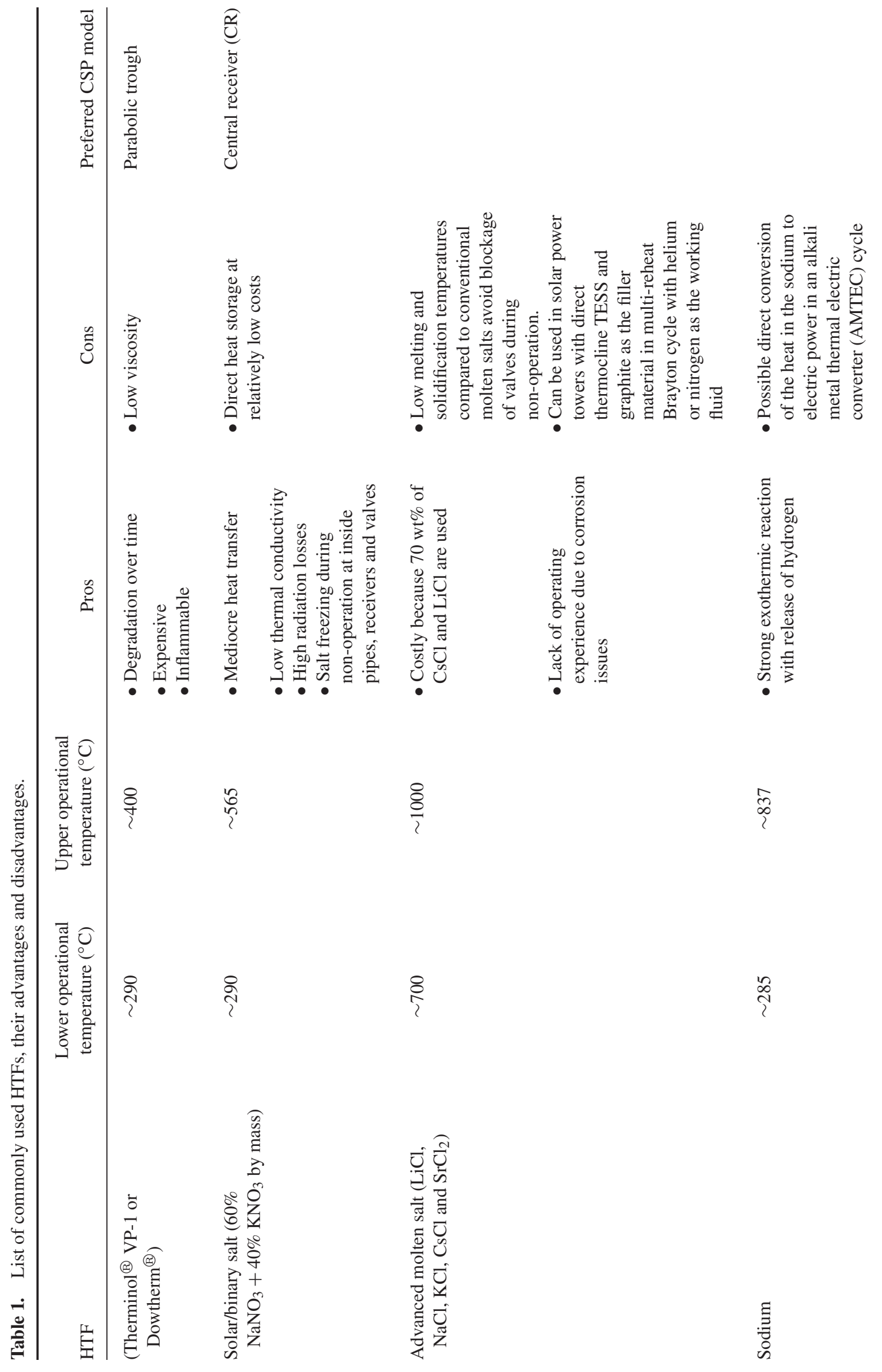




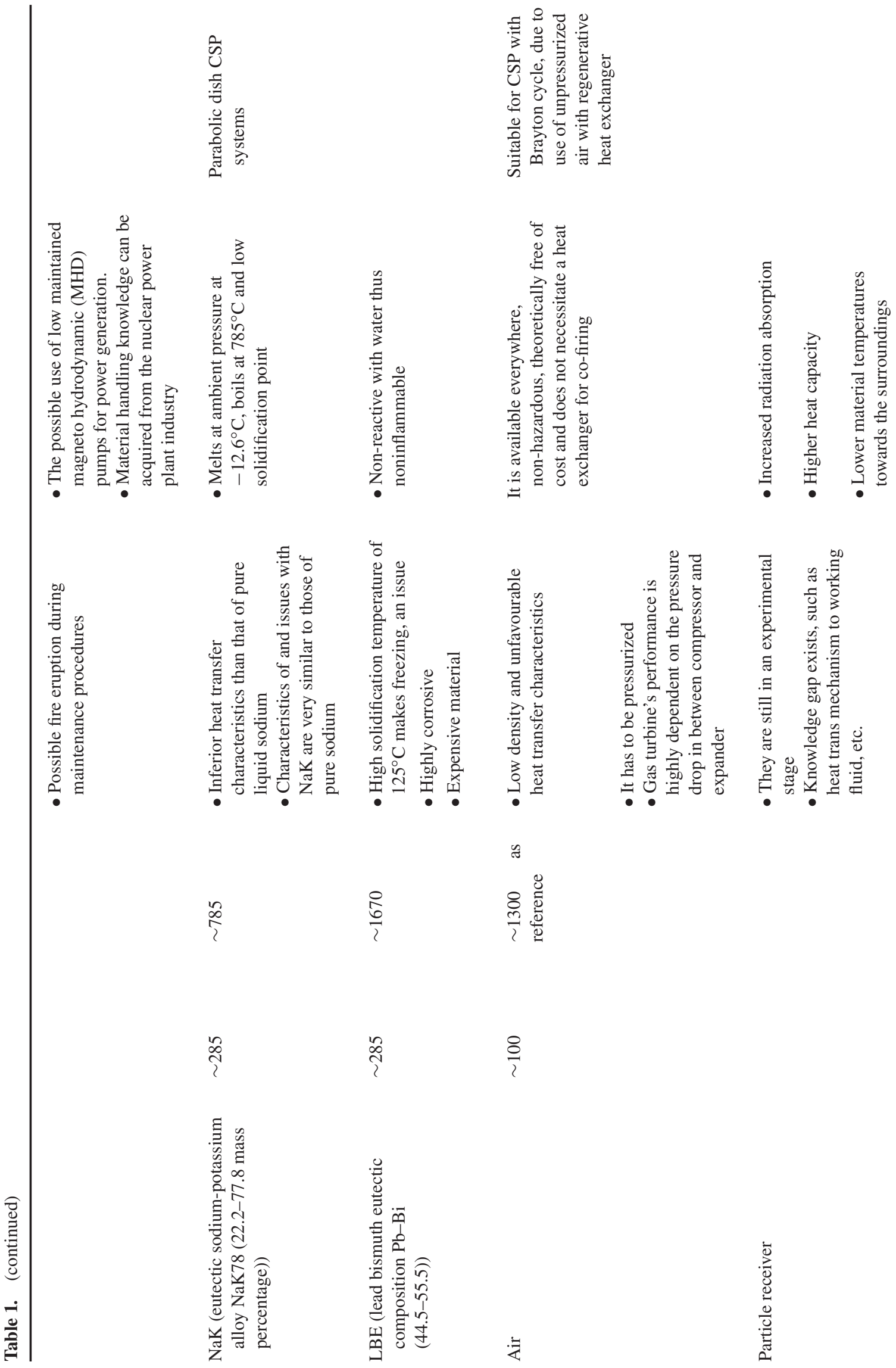




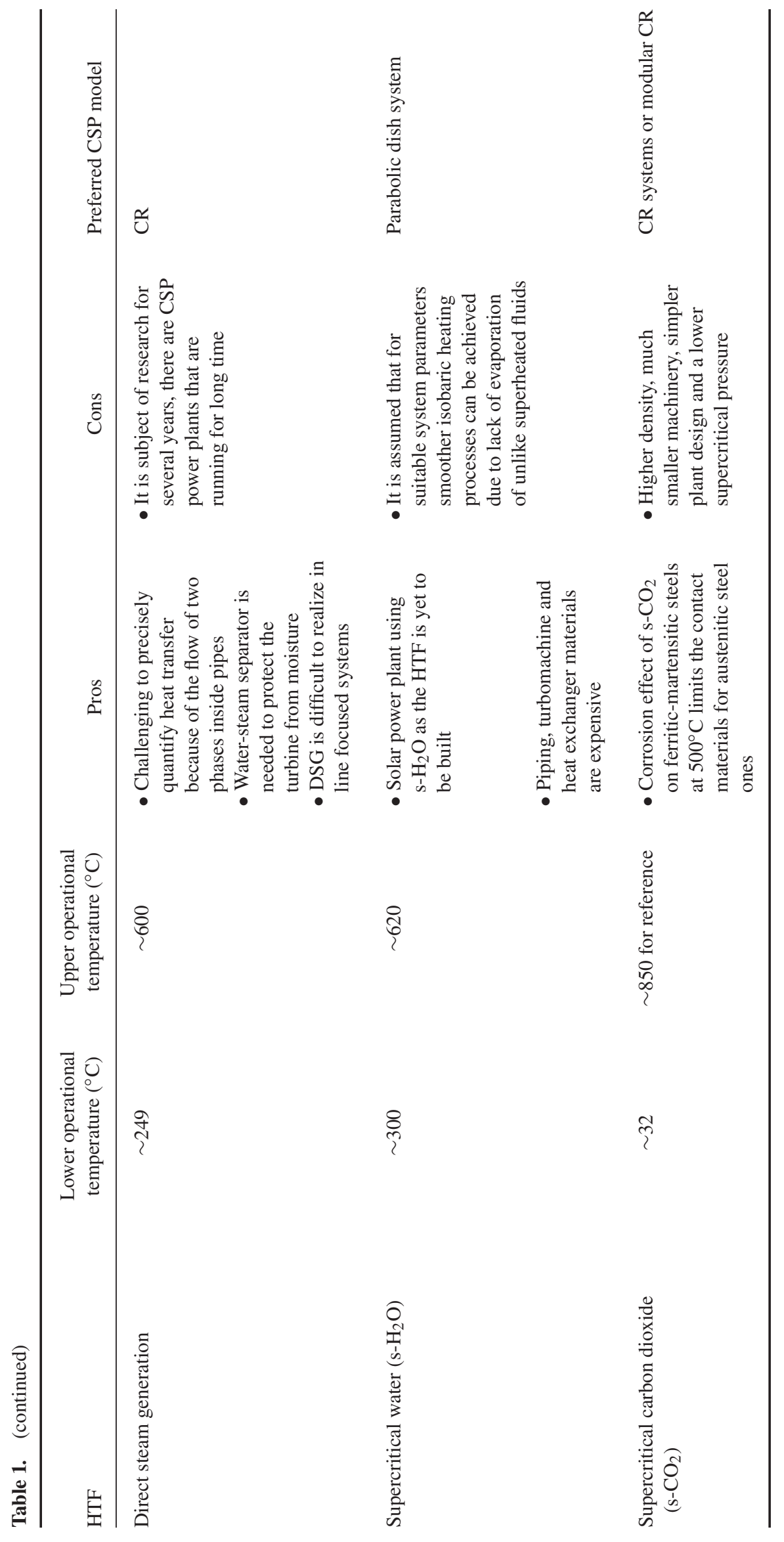


requirements. This problem could be overcome if the design and functioning of the reflector involves application of force on both edges of the reflecting sheet, along with the application of two additional forces, namely edge torsion force and pressing force [78]. This way not only the elastic buckling of the parabolic trough concentrator can be removed but also a theoretical maximum concentration ratio up to 115 can be achieved. This concept was also experimentally realized. Use of air as HFT along with novel concentrator designs [79] not only reduces the overall costs but also allows higher operating temperatures and integration with industrial processes.

\section{Solar water heating systems}

In India, solar water heating (SWH) systems are not only useful for household and commercial utilities but also for industrial utilities. As per MNRE, the total SWH potential in India is $\sim 40$ million $\mathrm{m}^{2}$ of collector area. By June 2010 , SWH systems covering 3.5 million $\mathrm{m}^{2}$ of collector area were installed and by the end of year 2022, a collector area of 20 million $\mathrm{m}^{2}$ is planned to be achieved. Considering all of the installed SWH systems in India, $3 \mathrm{~m}^{2}$ of collector area per 1,000 people could only be achieved. On the contrary, in countries such as Israel, wherein $80 \%$ of the household water heating is done with the aid of SWH systems, the collector area is $\sim 500 \mathrm{~m}^{2}$ per 1,000 people. JNNSM's target is to achieve 8 million $\mathrm{m}^{2}$ installed collector area by end of 2017. As per MNRE's estimates, yearly electricity of $\sim 1,500$ kWh can be saved for every 100-litre SWH system intended for just domestic use. In terms of costs, yearly INR. 7,500/can be saved if INR. 5/- is considered as the energy cost of $1 \mathrm{kWh}$. More importantly, peak power demand of $\sim 1 \mathrm{MW}$ can be saved per every thousand 100-litre SWH systems [80]. Market development and awareness programmes have been seriously taken up by the Indian government. SWH systems are included in the new national building code, GRIHA rating system for green buildings and energy conservation building codes.

\section{Other aspects related to solar energy materials}

\subsection{Other important materials in solar energy harvesting}

Glazing material is a transparent layer on solar cells or solar collectors that allows short-wave solar radiation into the cell and scatters away long-wave solar radiation. In recent years, vanadium dioxide attracted attention as an intelligent glazing material, which changes from metal to semiconductor phase with temperature. It changes its structure from rutile to monoclinic as the temperature is decreased and as a result electrical conductivity and optical properties are effected [81]. Moreover, the semiconductor phase is transparent to the solar radiation whereas metallic phase reflects solar radiation.
In an interesting innovative work from MIT, a low-cost one-sun, ambient steam generator (OAS) system was demonstrated. The OAS system consists of commercial spectrally selective coating on copper (to thermally concentrate heat) attached to a thermal form (which acts as the evaporation region) that floats on water. The entire system that floats on water is covered by a bubble wrap to minimize convective losses. Slots are cut in the bubble wrap to allow the steam to escape that is generated at $100^{\circ} \mathrm{C}$ [82]. The generated steam can be utilized in household water heating, generation of power and in various water-treatment applications.

Heat reservoirs are important sub-systems in solar power systems. In this context, phase change materials (PCMs) are used as isothermal heat reservoirs. PCMs exhibit large heat capacity values over a narrow range of temperatures. In endothermic phase change, PCMs transform from solid to liquid phase while in exothermic phase change, it is viceversa. PCMs exist in organic, inorganic and eutectic forms. Paraffins and non-paraffins constitute organic PCMs. Fatty acids (non-paraffins) are the most attractive organic PCMs. Inorganic PCMs include hydrated salts and metallic materials. When two or more components constituting minimummelting composition, in which each of the constituent melts and solidifies correspondingly to form a mixture of component crystallites, a eutectic is said to be formed. Eutectic PCMs exist in organic-organic, organic-inorganic and inorganic-inorganic forms. Eutectic PCMs are used as interior wallboards and tiles to maintain thermal environment in the room.

In solar power systems, certain materials are used for heat storage. These materials are classified as sensible-, latentand chemical-heat storage materials. Among these, sensibleheat storage materials are the most developed [83-85] even though they have the lowest storage capacity. On the other hand, latent-heat storage materials have much higher storage capacities, but they are poor heat transferors. Chemical storage materials have the highest storage capacities but handling these materials require specialized reactors. Chemical storage materials have poor long-term durability and stability.

\subsection{Requirements related to materials}

Protection layer: In conventional solar cells, protection layer is typically made of glass while in thin film solar cells it is made of transparent plastic. Both glass and plastic are mechanically not strong.

Front electric contact: This has to be transparent so that light travels into the cell. For thin film solar cells, it should also be conductive to collect charge carriers. Research efforts are directed towards preparing environmentally stable, lowcost and low-aperture continuous transparent electrodes, by combining metal nanostructures such as nanowires and grids with PEDOT or CNTs or with inks of carbon nanomaterials alone [86,87]. 
Absorption material: This is the most important material in the system. This is the material wherein the light is absorbed and converted into electric current. Most of the absorption materials are semiconductors (mostly Si is used). However, in order to improve the performance, multiple layers of different suitable materials have to be used and suitable doping has to be done.

Metal back contact: It is the contact at the back of the cell, which completes the solar cell circuit.

Laminate film: It ensures solar cells' physical structure, avoiding any damage through water and heat contact.

Back protection layer: It gives protection on the backside of the module. It is mostly made of glass; but Al or plastic may also be used.

Connectors and cables: They are used to connect the solar module to the load.

In concentrating photovoltaics (CPV) technology, an optical device is used to focus large area of sunlight onto the solar cell bringing-in three advantages namely: (i) use of only small amount of PV material, (ii) use of highly efficient multijunction solar cells which occupy very less space and (iii) use of ordinary and well-established methods to fabricate the optical system which is constituted by standard materials. Thus, CPV technology is less dependent on Si supply chain while use of optics brings-down the overall costs. Use of Fresnel lenses instead of standard lenses not only helps in achieving short focal lengths and large apertures, but also in lightweight systems. Since Fresnel lenses can be constructed in a circular shape, high concentration ratios $(\sim 500)$ can be achieved while maintaining point focus and thereby enabling the use of highly efficient multi-junction PV cells in the system instead of $\mathrm{Si}$ as in line concentrator. Fresnel lenses can also be constructed in a cylindrical shape enabling its use along with the regular line concentrator geometry.

In a hybrid system, multiple renewable energy sources are used in a cycle to minimize any inconsistencies when only a single source is used. For example, in northern hemisphere there is an inverse correlation between wind and sunshine; therefore use of sub-systems that enable the overall hybrid system to run on sunlight and wind in tandem helps in achieving optimal results.

At places where grid connectivity is a problem, surplus electrical energy generated from the renewable sources is often wasted because there is no mechanism to feed the surplus back to the grid. In this context, batteries (or any other suitable storage devices) should be used for storing the surplus energy, which can be used when required by discharging the batteries. When there is a requirement of continuous power supply, use of diesel engines may also be considered.

Solar roofing materials reduce the cost of household solar installations by generating electricity while protecting the buildings. These materials are aesthetically more pleasing than the rooftop-mounted panels. Building integrated photovoltaics (BIPV) are now being taken up in both large commercial and residential constructions owing to the recent advances in flexible thin-film PV materials that can be easily integrated into roofs and facades of the buildings. BIPV, if used regularly can reduce the costs associated with solar installations. In India, real estate business will continue to boom and therefore BIPV can have a large market share.

\subsection{Manufacturing, trading and service opportunities}

Development and regular use of solar power brings-in several opportunities to manufacture raw materials, components and accessories (like solar inverters) for solar PV thermal units and solar panels. Use of solar power also brings-in opportunities to manufacture products such as domestic solar water heaters, solar food cookers and industrial solar boilers. Opportunities to trade the above-mentioned systems, sub-systems and products will be consequently generated. Thereby, service opportunities such as installation and maintenance of the above-mentioned systems, sub-systems and products will be generated. Overall, employment for hardware engineers, system integrators and trainers will be generated. On the other hand, continuous research and development activities will open-up opportunities for budding scientists in this area.

\subsection{Market for manufacturing}

Planned investments in the advanced technologies such as nanofabrication have to be increased on an urgent basis so as create healthy and sustainable market for suitable equipment. Sharp increase in installed base of solar PV equipment may increase the market for manufacturing of various components. A report from Rocky Mountain Institute(R)(RMI.org) [88] stresses on the need of systems approach encompassing design, processes and scaling for yielding significant savings with the vision of a low-cost high-performance physical system design that can be tailored to unique site requirements, supporting business processes that can effectively, efficiently and predictably support solar deployment, making solar PV as the world's largest industry, utilizing an efficient supply chain based on common ground rules [88].

\subsection{Manufacturing}

In India, manufacturing of Si has to be taken up in a big-way. All the manufacturing processes such as ingot making, wafer cutting, recycling Si waste (from cutting) to useful $\mathrm{Si}$, casting ingots using $\mathrm{Si}$ waste, and so on have to be simultaneously developed and sustained. Si ribbon processing in which thin ribbons or sheets (their thickness is similar to that of Si wafer) of polycrystalline $\mathrm{Si}$ are drawn from a poly-Si melt has to be also developed because this will not involve wafer cutting process and therefore there will not be any $\mathrm{Si}$ waste.

In addition to Si processing, solar PV cell manufacturing has to be started. Cell manufacturing is technology-intensive and only through innovation-driven methodologies India's own Solar PV market can be developed. In case of solar 
modules for roofing purposes, modules with a lifespan of 20-25 years have to be manufactured. For outdoor installations, better plastic barrier films are needed and therefore manufacturing of such barrier films has to be taken up in order to avoid procurement of the same from specialized manufacturers.

Manufacturing of next-generation electrode-organic thinfilm cells on plastic should be given a great push. Continuous roll-to-roll processes involving printing of inks containing organic semiconductor materials dissolved in suitable solvents onto plastic substrates have to be developed. The materials used in this type of setups are inexpensive than the typical/conventional solar grade materials. However, the organic semiconducting materials are less efficient.

Conventional materials such as $\mathrm{Cd}$ using in the fabrication of solar PV cells are hazardous, while other materials such as plastics used for packaging are not biodegradable, and thereby they are not environment friendly. Therefore, materials that are either environment friendly or biodegradable have to be developed and used. Processes to recycle the waste generated during different manufacturing steps of the solar cells have to be developed. Manufacturing of solar glass with high solar transmission, good mechanical strength, self-cleaning characteristics and lamination and coating feasibility has to be taken up. Similarly, production of mirrors (with high solar reflectance and good specular reflectance characteristics) that are used to concentrate the solar light onto either PV material or a thermal receiver has to be taken up. The formation of dust and ice (especially in cold countries) on solar panels will deteriorate their performance. To mitigate ice formation, techniques such as heating solar panels, spraying hot air/water, arranging solar panels on inclined roofs are followed. However, all of the above techniques are not economically viable [89]. To mitigate formation of foreign particles, and ice formation self-cleaning coatings are employed. The surfaces of self-cleaning coatings are either hydrophilic or hydrophobic in nature [90]. Inspiration for developing aesthetic self-cleaning functional surfaces has been derived from the examples in nature such as the lotus leaf that rises from muddy waters, yet its surface remains clean. The self-cleaning mechanism of the lotus leaf surface was found to be due to its microscopic roughness [91] and the presence of epicuticular wax crystalloids, which made the lotus leave surface superhydrophobic. In general, superhydrophobicity in nature was found to be strongly influenced by hierarchical micro- and nano-structures or unitary microline surface structures. Self-cleaning coatings effectively use water as the medium to clean themselves. In hydrophilic coatings, water is made to spread over coating and carries away dust particles with it. On the other hand, in hydrophobic coatings water droplet slide and rolls over coating surface and pushes away the impurity particles. The term called contact angle is an important parameter for self-cleaning technologies. Super (or ultra) hydrophobic (contact angle $>150^{\circ}$ ) coatings are beneficial for solar cells maintenance.
For ice formation, air at the interface has to be supersaturate. However, this supersaturation degree is more for low energy surface, since the superhydrophobic surfaces are extreme low energy surface they require higher supersaturation degree that automatically disturbs ice formation. Hydrophobic and superhydrophobic surfaces are made either by (i) creating a rough surface on a low surface-energy material or (ii) modifying a rough surface with a low surface-energy material. Under category (i) silicones such as polydimethylsiloxane; fluorocarbons such as polytetrafluoroethylene; organic materials such as low-density polyethylene, polystyrene, alkylketene, polycarbonate, and polyamide; inorganic materials such as $\mathrm{ZnO}$ and $\mathrm{TiO}_{2}$ are well studied and in most of the cases water contact angle is more than $160^{\circ}$. In recent years, aluminium oxide superhydrophobic coatings were developed on glass substrates through solution-based approach for solar panel cover glass applications [92]. The prepared coatings showed static contact angle of $161^{\circ}$ and tilt angle less than $10^{\circ}$. A comparison was drawn between uncoated and coated glass substrates covered with sawdust when used as solar glass covers. The uncoated glass substrate and aluminium oxide-coated superhydrophobic glass substrate exhibited the efficiency of sawdust-contaminated solar panel by 67 and $91 \%$, respectively. Different chemical (such as wet-chemical method, hydrothermal method, electro-chemical deposition, chemical vapour deposition, sol-gel method, polymerization reaction etc.) and physical methods (such as self-assembly and layer-by-layer deposition, lithography, electrospinning etc.) are used to modify the surface of different materials under the category (ii). On the other hand, $\mathrm{TiO}_{2}$ is well-studied material for hydrophilic self-cleaning type coatings.

\section{Energy storage materials and other technologies}

As discussed in the Introduction, solar PV technology is still considered as an intermittent energy supplier (owing to the continuous variations in the climate) and therefore it has to be supported by energy storage devices such as batteries, supercapacitors and $\mathrm{H}_{2}$ storage devices. Functionality is vital for any new energy storage material. In the case of hydrogen storage, new materials that can store hydrogen in a large fraction of their weight/volume are needed. In the case of ultracapacitors, development of novel electrode materials is the need of the hour. Similarly, there is a great requirement to develop novel dielectric materials, which aid in the operation of ultracapacitors at higher voltages such that high-power applications can be realized. Novel electrochemistry concepts and novel electrode materials that can give efficient battery technology are also the need of the hour.

Apart from harvesting solar energy, India has Civil Nuclear Energy Programme to produce clean and safe energy. Six different type of nuclear reactors, namely light water reactors, European pressurized reactors, pressurized heavy water reactors (PHWR), advanced heavy water reactors and fast breeder 
reactors are being established at different locations in India. The estimated output capacity of all these nuclear plants by year 2030 is estimated as $20.9 \mathrm{GW}$ and by the year 2050 it is estimated as 52 GW. PHWR is India's indigenous technology, which uses natural Uranium as the active material and it is cost effective compared with other technologies.

\section{Conclusions}

Owing to the easy availability of Si in comparison to other materials, Si-based solar PV technology has matured largely and most of the high capacities harnessing establishments are based on it. Although the solar PV technology and the associated market look healthy, there is an urgent need to overcome a number of important challenges, namely feedstock supply, management of the available resources, development of novel solar grade materials, enhancing efficiency of known materials using concepts of nanoscience, development of novel designs, development of processing innovations, and costly processing/manufacturing methods on an urgent basis. On the other hand, Governments all over the world should make energy policies that can help in reduction of carbon capture in the whole world. In this regard, Governments should collaborate amongst themselves setting aside any differences. For any Government to make good energy policies by overcoming social and political constraints, it should educate its own people about the consequences and also allow its own people in formulating policies by encouraging them to give ideas and requirements at the ground level.

With regard to the industry, good collaborations between cell manufacturers, equipment and material suppliers and marketing fraternity have to be encouraged and closely monitored. The problem of energy is so big that the industry should realize to put aside big margin financial gains over the protection of nature by using renewable energy. Innovations have to be encouraged in general and the solar PV cell and module manufacturers should be courageous to take up innovative research and development. This may not only improve the quality of solar PV technology but might also reduce manufacturing costs. Well-to-do business houses should make spirited investments in the solar PV industry. Indian government's liberal energy policies with respect to renewable energy have definitely given good results. At the same time, it is also important for the Indian government to properly disburse funds to continue non-renewable technologies. Indian industries should take up the challenges of processing advanced solar grade materials and solar cells' fabrication. Sub-area specializations and the concerned specialists (i.e., materials' physicists, chemists and cell fabrication engineers) in solar energy harvesting have to be encouraged. Interestingly, Indian renewable energy market share in rural India is enormous even when there are plenty of limitations. Overall, India is definitely in an advantageous position as far as instilling solar energy in various sectors.

\section{References}

[1] EIA 2006 U.S. Energy Information Administration

[2] Watkins K 2006 Human Development Report

[3] Jacobson M Z and Delucchi M A 2011 Energy Policy 39 1154

[4] Jacobson MZ, Delucchi M A, Bazouin G, Bauer Z A F, Heavey C C, Fisher E et al 2015 Energy Environ. Sci. 82093

[5] http://www.nrel.gov/gis/solar.html

[6] http://www.nrel.gov/international/ra_india.html

[7] Sharma N K, Tiwari P K and Sood Y R 2012 Renew. Sustainable Energy Rev. 16933

[8] http://www.mnre.gov.in/solar-mission/jnnsm/introduction-2

[9] http://www.mnre.gov.in/file-manager/UserFiles/mission_doc ument_JNNSM.pdf

[10] http://mnre.gov.in/file-manager/UserFiles/State-wise-Installe d-Capacity-of-Solar-PV-Projects-under-various-Scheme.pdf

[11] Glavin M E, Chan P K W, Armstrong S and Hurley W G $200813^{\text {th }}$ International Power Electronics Motion Control Conference IEEE 1688, Poznan Univ. of Technology, Poznan, Poland

[12] Samson G T, Undeland T M, Ulleberg O and Vie P J S 2009 International Conference Clean Electrical Power IEEE 141 Palazzo dei Congressi - Capri, Capri, Italy

[13] Thounthong P, Chunkag V, Sethakul P, Sikkabut S, Pierfederici S and Davat B 2011 J. Power Sources 196313

[14] Fan Z, Razavi H, Do J, Moriwaki A, Ergen O, Chueh Y L et al 2009 Nat. Mater. 8648

[15] Priolo F, Gregorkiewicz T, Galli M and Krauss T F 2014 Nat. Nanotechnol. 919

[16] http://pubs.usgs.gov/fs/2002/fs087-02/

[17] Green M A, Emery K, Hishikawa Y, Warta W and Dunlop E D 2016 Prog. Photovolt: Res. Appl. 243

[18] http://www.iea-pvps.org/fileadmin/dam/public/report/PICS/I EA-PVPS_A_Snapshot_of_Global_PV_-_1992-2015_-_Fin al_2_02.pdf

[19] Wadhwa I 2011 Saket Press 157

[20] http://www.plgrenewables.com/

[21] http://powermin.nic.in/

[22] Jayawardena K D G I, Rozanski L J, Mills C A, Beliatis M J, Nismy N A and Silva S R P 2013 Nanoscale 58411

[23] Campbell P and Green M A 2001 Sol. Energ. Mat. Sol. Cells 65 369

[24] Bohren C F and Huffman D R 2008 Absorption and scattering of light by small particles John Wiley \& Sons, ISBN: 978-0471-29340-8

[25] Brongersma M L, Cui Y and Fan S 2014 Nat. Mater. 13451

[26] Spinelli P, Verschuuren M A and Polman A 2012 Nat. Commun. 3692

[27] Catchpole K R and Polman A 2008 Appl. Phys. Lett. 93 191113

[28] Spinelli P, Macco B, Verschuuren M A, Kessels W M M and Polman A 2013 Appl. Phys. Lett. 102233902

[29] Van de Groep J, Spinelli P and Polman A 2012 Nano Lett. 12 3138

[30] Mokkapati S, Beck F J, Polman A and Catchpole K R 2009 Appl. Phys. Lett. 95053115

[31] Ferry V E, Verschuuren M A, Van Lare M C, Schropp R E I, Atwater H A and Polman A 2011 Nano Lett. 114239 
[32] Morfa A J, Rowlen K L, Reilly T H, Romero M J and Van de Lagemaat J 2008 Appl. Phys. Lett. 92013504

[33] Dingemans G and Kessels W M M 2012 J. Vac. Sci. Technol. A: Vacuum, Surfaces, and Films 30040802

[34] Spinelli P, Hebbink M, de Waele R, Black L, Lenzmann F and Polman A 2011 Nano Lett. 111760

[35] Spinelli P and Polman A 2014 IEEE J. Photovolt. 4554

[36] Spinelli P, Lenzmann F, Weeber A and Polman A 2015 IEEE J. Photovolt. 5559

[37] Sum T C and Mathews N 2014 Energy Environ. Sci. 72518

[38] Kojima A, Teshima K, Shirai Y and Miyasaka T 2009 J. Am. Chem. Soc. 1316050

[39] Im J H, Lee C R, Lee J W, Park S W and Park N G 2011 Nanoscale 34088

[40] Kim H S, Lee C R, Im J H, Lee K B, Moehl T, Marchioro A et al 2012 Sci. Rep. 2591

[41] Kim H S, Lee J W, Yantara N, Boix P P, Kulkarni S A, Mhaisalkar S et al 2013 Nano Lett. 132412

[42] Etgar L, Gao P, Xue Z, Peng Q, Chandiran A K, Liu B et al 2012 J. Am. Chem. Soc. 13417396

[43] Laban W A and Etgar L 2013 Energy Environ. Sci. 63249

[44] Lee M M, Teuscher J, Miyasaka T, Murakami T N and Snaith H J 2012 Science 338643

[45] Ball J M, Lee M M, Hey A and Snaith H J 2013 Energy Environ. Sci. 61739

[46] Carnie M J, Charbonneau C, Davies M L, Troughton J, Watson T M, Wojciechowski K et al 2013 Chem. Commun. 497893

[47] Wojciechowski K, Saliba M, Leijtens T, Abate A and Snaith H J 2014 Energy Environ. Sci. 71142

[48] Swarnkar A, Marshall A R, Sanehira E M, Chernomordik B D, Moore D T, Christians J A et al 2016 Science 35492

[49] Mei A, Li X, Liu L, Ku Z, Liu T, Rong Y et al 2014 Science 345 295

[50] Burschka J, Pellet N, Moon S J, Humphry-Baker R, Gao P, Nazeeruddin M K et al 2013 Nature 499316

[51] Im J H, Jang I H, Pellet N, Grätzel M and Park N G 2014 Nat. Nanotechnol. 9927

[52] Saliba M, Matsui T, Seo J Y, Domanski K, Correa-Baena J P, Nazeeruddin M K et al 2016 Energy Environ. Sci. 91989

[53] Hao F, Stoumpos C C, Cao D H, Chang R P H and Kanatzidis M G 2014 Nat. Photon. 8489

[54] Noel N K, Stranks S D, Abate A, Wehrenfennig C, Guarnera S, Haghighirad A A et al 2014 Energy Environ. Sci. 73061

[55] Murali B and Krupanidhi S B 2014 Dalton Trans. 431974

[56] Krebs F C 2009 Sol. Energ. Mat. Sol. Cells 93394

[57] Søndergaard R R, Markus H and Frederik C K 2013 J. Polym. Sci. Part B Polym. Phys. 5116

[58] Abdin Z, Alim M A, Saidur R, Islam M R, Rashmi W, Mekhilef S et al 2013 Renew. Sustainable Energy Rev. 26837

[59] Nagavolu C, Susmitha K, Raghavender M, Giribabu L, Bhanu Sankara Rao K, Smith C T G et al 2016 Solar Energy 137143

[60] Murakami T N, Kawashima N and Miyasaka T 2005 Chem. Commun. 03346
[61] Cohn A P, Erwin W R, Share K, Oakes L, Westover A S, Carter R E et al 2015 Nano Lett. 152727

[62] Ng C H, Lim H N, Hayase S, Harrison I, Pandikumar A and Huang N M 2015 J. Power Sources 296169

[63] Chien C T, Hiralal P, Wang D Y, Huang I S, Chen C C, Chen C W et al 2015 Small 112929

[64] Zhao J, Li Y, Yang G, Jiang K, Lin H, Ade H et al 2016 Nat. Energy 115027

[65] Green M A 2006 Third generation photovoltaics (Berlin Heidelberg: Springer)

[66] http://www.nrel.gov/ncpv/

[67] Chow T T 2010 Appl. Energy 87365

[68] Franz Trieb C S, Marlene O`Sullivan T and Pregger C H K 2009 In Solar Power Solar Paces Conference, Berlin, Germany

[69] TERI Newswire 2010 The Hindu Business Line 16(8)

[70] TERI Newswire 2010 The Hindu Business Line 16(10)

[71] http://www.acme.in/solar-thermaltechnology.asp?links=13a

[72] https://www.ntpc.co.in/index.php?option=com_content\&vie $\mathrm{w}=$ article $\& \mathrm{id}=206 \&$ lang $=\mathrm{en}$

[73] http://www.mnre.gov.in/pdf/jnnsmgridconnected-25072010. pdf

[74] http://mnre.gov.in/pdf/mission-document-JNNSM.pdf

[75] Heller L 2013 Literature review heat transfer fluidsthermal energy storage systems CSP Plants STERG Report

[76] Srivastva U, Malhotra R and Kaushik S 2015 J. Fundam. Renewable Energy Appl. 51

[77] Rodríguez J M, Sánchez D, Martínez G S, Bennouna E G and Ikken B 2016 Solar Energy 140206

[78] Qiu Z, Li P, Li C, Zhu Q, Zhang T and Wang C 2017 Solar Energy 14159

[79] Good P, Ambrosetti G, Pedretti A and Steinfeld A 2016 Solar Energy 139398

[80] http://www.mnre.gov.in/Solar-water-heaters/briefswhs.pdf

[81] Rogers K D 1993 Powder Diffr. 8240

[82] Ni G, Li G, Boriskina S V, Li H, Yang W, Zhang T and Chen G 2016 Nat. Energy 116126

[83] P S I GmbH 2000 Survey thermal storage parabolic trough power plants NREL/SR -550-27925

[84] Zhao C Y and Wu Z G 2011 Sol. Energ. Mat. Sol. Cells 95 3341

[85] Zhao C Y, Zhou D and Wu Z G $201014^{\text {th }}$ International Heat Transfer Conference ASME 7435

[86] Ellmer K 2012 Nat. Photon. 6809

[87] Hecht D S, Hu L and Irvin G 2011 Adv. Mater. 231482

[88] Bony L, Stephen D, Chris H, Maurer E and Newman S 2010 Rocky Mountain Institute Report

[89] Jelle B P 2013 Energy Build. 67334

[90] Ganesh V A, Raut H K, Nair A S and Ramakrishna S $2011 \mathrm{~J}$. Mater. Chem. 2116304

[91] Solga A, Cerman Z, Striffler B F, Spaeth M and Barthlott W 2007 Bioinspir. Biomim. 2 S126

[92] Sutha S, Suresh S, Raj B and Ravi K R 2017 Sol. Energy Mat. Sol. Cells 165128 